DEPARTMENT OF THE INTERIOR-U, S, GEOLOGICAL SURVEY CHARLES D. WALCOTT, DIRECTOR

\title{
TH $\mathrm{E}$
}

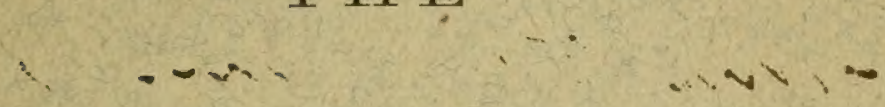

\section{FORESTSYOF THE UNITED STATES}

BY

\section{HENRY GANNETT}

EXTRACT FROM THE TWENTIETH ANNUAL REPORT OF THE SURVEY, 1898-99 PART $V$, FOREST RESERVES-HENRY GANNETT; CHIEF OF DIVISION OF GEOGRAPHY AND FORESTRY

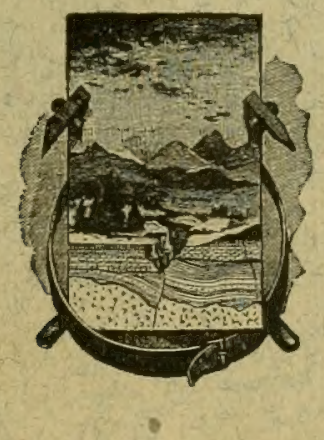

WASHINGTON GOVERNMENT. PRINTING OFEICE 1900 



\section{THE FORESTS OF THE UNITED STATES}

BY

HENRY GANNETT 



\title{
FOREST RESERVES.
}

\author{
Henry Gannett, Chief of Division. \\ THE FORESTS OF THE UNITED STATES. \\ CHANGES IN RESERVES DURING THE YEAR.
}

During the fiscal year numerous changes have been made in forest reserves, including several modifications of boundary lines, resulting in a considerable net increase to existing reserves and in the addition of new reserves. The boundaries of the Black Hills Reserve, in South Dakota, have been changed by the exclusion of a large area in the south and the inclusion of a much larger area in the north and west, the additions in the west being within the State of Wyoming. These changes have resulted in increasing the area of the reserve from 967,680 to $1,211,680$ acres. The Pecos River Reserve, in New Mexico, has been extended by a narrow strip upon the east and a considerable addition upon the north.

The additional reserves created during the year are Fish Lake, in Utah; Gallatin, in Montana; Gila, in New Mexico; Lake Tahoe, Pine Mountain and Zaca Lake, in California, and Black Mesa, Prescott, and San Francisco Mountains, in Arizona.

\section{PRESENT CONDITIONS.}

By these changes an area exceeding 11,000 square miles has been added to the reserves during the year.

The following is a list of the reserves as they stood on July 1, 1899, with their areas:

Names, location, and areas of forest reserves, July 1, 1899.

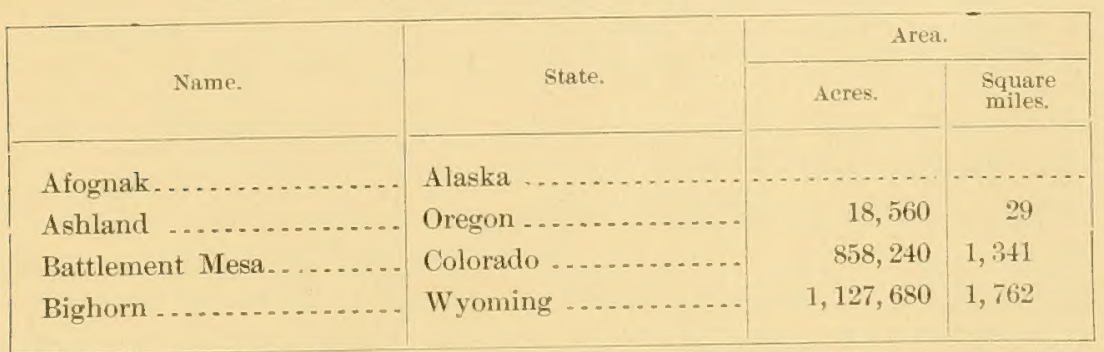

20 GEOL, PT $5-1$ 
Nomes, location, and areas of forest reserves, July 1, 1899 - Continued.

\begin{tabular}{|c|c|c|c|}
\hline \multirow{2}{*}{ Name. } & \multirow[b]{2}{*}{ State. } & \multicolumn{2}{|c|}{ Area. } \\
\hline & & Acres. & $\begin{array}{l}\text { Square } \\
\text { Miles. }\end{array}$ \\
\hline Bitterroot .... & Idaho and Montana ... & $4,147,200$ & 6,480 \\
\hline Black Hills ... & South Dakota....... & $1,211,680$ & 1,893 \\
\hline Black Mesa .. & Arizona.... & $1,658,880$ & 2,592 \\
\hline Bull Run . & Oregon .... & 142,080 & 222 \\
\hline Cascade .... . & ..... do .... & $4,492,800$ & 7,020 \\
\hline Fish Lake .... & Utah........ & 67,840 & 106 \\
\hline Flathead .... & Montana ..... & $1,382,400$ & 2,160 \\
\hline Gallatin - & ..... do ... & 40,320 & 63 \\
\hline Gila........ & New Mexico ... & $2,327,040$ & 3,636 \\
\hline Grand Canyon.. & Arizona ..... & $1,851,520$ & 2,893 \\
\hline Lake Tahoe.... & California .... & 136,335 & 213 \\
\hline Lewis and Clarke. & Montana .... & $2,926,080$ & 4,572 \\
\hline Mount Rainier.. & Washington .. & $2,234,880$ & 3,492 \\
\hline Olympic....... & ..... do ........ & $2,188,800$ & 3,420 \\
\hline Pecos River..... & New Mexien ... & 431,040 & 673.5 \\
\hline Pikes Peak .... & Colorado .... & 184,320 & 288 \\
\hline $\begin{array}{l}\text { Pine Mountain and Zaca } \\
\text { Lake. }\end{array}$ & California.. - & $1,644,594$ & $2,569.6$ \\
\hline Plum Creek..... . & Colorado ... & 179,200 & 280 \\
\hline Prescott ..... & Arizona ..... & 10,240 & 16 \\
\hline Priest River...... . & Idaho and Washington - & 645,120 & 1,008 \\
\hline San Bernardino ........... & California .... & 737,280 & 1,152 \\
\hline San Francisco Mountains .- & Arizona ..... & 975,360 & 1,524 \\
\hline San Gabriel....... . & California.... & 555,520 & 868 \\
\hline San Jacinto..... & .....do .... & 737,280 & 1,152 \\
\hline Sierra .......... . & ..... do .... & $4,096,000$ & 6,400 \\
\hline South Platte.. & Colorado .... & 683,520 & 1,068 \\
\hline Stanislaus ..... & California ... & 691,200 & 1,080 \\
\hline Teton ............. & Wyoming..... & 829,440 & 1,296 \\
\hline Trabuco Canyon. & California .. & 49,920 & 78 \\
\hline Uinta ....... & Utah ........ & 875,520 & 1,368 \\
\hline Washington ........ & Washington.... & $3,594,240$ & 5,616 \\
\hline White River Plateau . & Colorado ..... & $1,198,080$ & 1,872 \\
\hline Yellowstone... & Wyoming ... & $1,239,040$ & 1,936 \\
\hline Total ... & & $46,169,249$ & 72,139 \\
\hline
\end{tabular}

There is, therefore, reserved from settlement at present an area of 72,139 square miles. It is composed mainly of mountainous, rugged country, of no value for agriculture, but especially favorable for tree growth. The locations of the reserves are shown on PI. I, in pocket at the end of this volume. 
Of these reservesexaminations have been made by this office of the following: Battlement Mesa, Bighorn, Bitterroot, Black Hills, Flathead, Pikes Peak, Plum Creek, Priest River, San Bernardino, San Gabriel, San Jacinto, South Platte, Teton, Washington, and White River Plateau. Besides these the Mount Rainier, Olympic, and Yellowstone reserves have been examined in part.

The reserves thus far examined comprise an area of 28,236 square miles, or about 39 per cent of the entire area of the reserves.

The following are the areas reserved in each State and Territory, with the proportion which the reserved area bears to the total area and to the wooded area of each State or Territory:

Areas of forest reserves by States, in square miles and in percentages of area and of wooded areas.

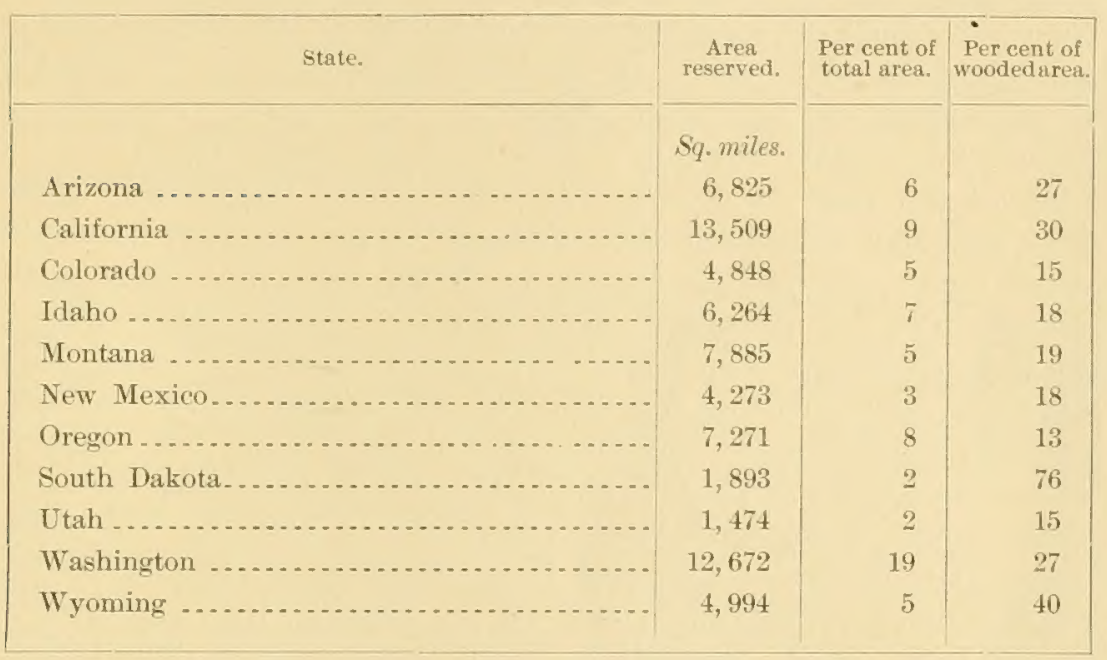

Of the total area it appears that a much larger proportion of Washington has been reserved than of any other State or Territory. Of the wooded area the proportion ranges from 13 per cent in Oregon to 76 per cent in South Dakota, where nearly all the woodland has been reserved from settlement.

\section{ABSTRACTS OF REPORTS ON FOREST RESERVES.}

\section{PIKES PEAK, PLUM CREEK, AND SOUTH PLATTE RESERVES.}

There are in Colorado five reserves, known as Pikes Peak, Plum Creek, South Platte, White River, and Battlement Mesa reserves. Of these the first three were examined by Mr. John G. Jack and the last two by Mr. George B. Sudworth.

The three reserves, Pikes Peak, Plum Creek, and South Platte, are in the central part of the State and lie contiguous to one another. The first comprises an area of 184,320 acres, or 288 square miles, 
including the summit of Pikes Peak and its slopes and spurs to the north, south, and west. The second comprises an area of 179,200 acres, or 280 square miles, including the rugged, granite country immediately to the west of Pikes Peak, traversed by the South Platte. The third comprises an area of 683,520 acres, or 1,068 square miles, and includes the high mountains upon the east, north, and west of South-Park.

The surface of these reserves lies at rather high altitudes, ranging from 7,000 feet in the lowest valleys to 14,000 feet upon the summits of the mountains. It is, in the main, a rugged mountain region, heavily eroded, with thin, coarse soil, mainly of granite detritus, and very little of it is suited for any other purpose than the production of forests.

Owing to the great altitude the climate is rather severe, and even in the most favored localities only very limited agriculture is possible. The crops which can be produced consist only of the hardiest grains and vegetables, while nearly all the land within the area is incapable of supporting any agriculture whatever. The rainfall, however, is ample for the support of forests over nearly the entire region.

Of all the reserves established by the Federal Goverument these three probably have been most damaged by fire and have been subjected to the greatest depredation by timber cutters. Only a small proportion of the total area of these reserves is without traces of fires, and large areas have been burned over in comparatively recent years. Moreover, timber cutting has been very widespread, the forests having been culled almost everywhere of their largest and most valuable trees. As a result of the fires and of the cutting, the timber is everywhere small, occurring in scattered groves, alternating with open areas. It is nowhere dense, and the older trees are very defective. There is much undergrowth, showing the disposition of the forest to reassert itself, but in the entire area of these reserves there is altogether very little merchantable timber.

The principal timber trees found in these reserves are the following:

Pinus ponderosa (yellow pine).- This is the most abundant, the most widely distributed, and the most valuable species found within this area. It attains a larger growth than other trees, the extreme limit observed being 125 feet in height and exceeding 3 feet in diameter. It is found ranging from the lowest altitude within the reserve up to about 10,000 feet.

Pinus murrayana (lodgepole pine) is abundant, sometimes being found mixed with other pines and spruces, at other times forming pure growths. As everywhere else in the Rocky Mountain region, this species is here increasing its range, being the first to restock burned areas. It is of little commercial value.

Psendotsuga taxifolia (red fir, Douglas spruce).-This tree is found 
closely associated with the yellow pine, occupying practically the same belt of altitude. It grows here to a considerable size, although not to be compared in this respect with its development on the Pacific coast. The extreme height observed was 120 feet, with a trunk 4 feet in diameter.

Picea engelmanni (Engelmann spruce). - This tree is abundant at considerable altitudes, reaching its best development between 10,000 and 11,000 feet, where it is sometimes found 120 feet in height, with a diameter exceeding 3 feet.

Picea parryana (blue spruce).-This tree is nowhere abundant and never occurs by itself, being mixed with other species. Its range is from the lowest altitudes up to about 9,000 feet.

Abies lasiocarpa (alpine fir).-This tree is here of rare occurrence, being found sparsely at the greatest altitudes.

Abies concolor (balsam fir).-This also is of rather rare occurrence, and is of little importance from an economic point of view.

Other species found within the reserves which are of little or no economic importance are the piñon pine, two species of juniper, quaking aspen, and cottonwood.

PIKES PEAK RESERVE.

The Pikes Peak Reserve is traversed by the Colorado Midland Railway, on which are several stations, a number of them being in the nature of summer resorts, containing few inhabitants except in the summer season. The northeastern corner of the reserve is touched by the Denver and Rio Grande Railroad, and a considerable town has been built up at Palmer Lake within the limits of the reserve.

Scattered over the reserve are a number of small ranches, as along Bear and North Cheyenne creeks, and upon the Cheyenne Mountain wagon road, between Cheyenne Springs and Cripple Creek. There is little agriculture possible in this reserve, and little has been attempted, the ranches being chiefly devoted to the raising of cattle.

There are no active mines within this reserve, although much prospecting is being done.

There are no sawmills at present at work within the reserve, but much cutting has been done in past years.

PLUM CREEK RESERVE.

A considerable proportion, perhaps a third, of the area of the Plum Creek Reserve is under private ownership, the lands thus held being as a rule those at the lowest altitudes and having the most level surface.

The western side of this reserve has, in recent years, been the scene of intense mining excitement, which resulted in the establishment of a number of small mining towns. The boom, however, having sub- 
sided, these towns are largely deserted at present. There are now no paying mines within the reserve, although many prospects are held and work is being done upon them.

Much lumbering is still carried on in this reserve, there being at the time of the examination no fewer than six portable sawmills at work, altogether capable of turning out 60,000 or 70,000 feet of lumber per day. The owners of these mills claim to be cutting timber upon land held in private ownership.

SOUTH PLATTE RESERVE.

In the South Platte Reserve are several towns of considerable magnitude, such as Alma, Park City, and East Leadville. The western portion of the reserve is traversed by a branch of the Coiorado and Southern Railway and by the Colorado Midland Railway, which have stations located within it. Altogether, although a comparatively small proportion of the reserve has been alienated, there is a considerable population living within its limits.

Only small portions of this reserve lie at altitudes sufficiently low to permit agriculture, even upon the most limited scaie, to be carried on, and but little farming is attempted. Cattle and sheep are grazed to a considerable extent in the margin of South Park, which lies within the reserve.

The northern and western borders of South Park lying within the reserve have in years past been the scene of active placer mining; considerable quartz mining also has been done. At present the mining industry in this region is not in a profitable condition; still there are numerous mining camps, some new and some old, within the region. Among these are Puma, Gold City, Jasper, Alma, Park City, East Leadville, and Sacramento.

Timber eutting, especially in the mountains on the north and west of South Park, has in years past been extremely active for the supply of the mines, especially those at Leadville, but at the time of the examination of this reserve there were only four or five mills at work, probably upon timber owned by private parties.

These reserves can not be regarded as sources of supply of timber at present, or for many years to come, but rather as areas for its cultivation. Through fires and timber cutting nearly all the timber of value has been destroyed, and it will require generations of care and protection before this area can again become a source of supply.

\section{BATTLEMENT MESA FOREST RESERVE.}

This reserve was examined by Mr. George B. Sudworth during the months of September and October, 1898. It is situated in western Colorado, between Grand and Gunnison rivers. The area of the reserve is 1,321 square miles, or 858,240 acres. 
The surface of this reserve is composed largely of high plateaus, whose summits range from 10,000 to 12,000 feet in altitude. Being mainly a greatly elevated region, it enjoys a rainfall ample for the growth of forests. Still, despite this ample rainfall, it is not by any means a heavily forested region. The trees occur in groves, alternating with areas of open park, and as a rule are small and of a species of no great value for industrial purposes. Altogether the stand of timber upon the reserve is estimated to be not more than 150 million feet B. MI.

The most salient features of this reserve are the two high mesas, known as Grand and Battlement mesas. The latter is comparatively small, its summit covering but a few square miles, separating Grand River from the upper waters of Plateau Creek. Its altitude is fully 12,000 feet above the sea. It is composed in the main of sandstones, with a lava cap, which has protected it from erosion.

Grand Mlesa is much larger and rises with long slopes from the ralley of Gunnison River on the south and west to an altitude of 10,000 to 11,000 feet. Like Battlement Mesa, it is composed mainly of sandstones, with a lava capping, which in parts has been broken away by undermining, leaving here and there lava summits, while at the western part the lava cap still remains intact, covering a considerable area.

The principal trees occurring in this reserve are, in the order of their importance, as follows:

Engelmann spruce and alpine fir, which are always associated together in the forests, are the most conspicuous and abundant and cover the largest areas. Of these mixed forests the spruce forms about three-fourths of the timber. They occur mainly between 8,000 and 10,500 feet above the sea. Neither tree grows to large size, larely exceeding 70 feet in height and 14 or 15 inches in diameter.

Red fir, or Donglas spruce, is found in small groves and single trees, between the altitudes of 6,500 and 9,800 feet. The extreme size of this tree is 30 inches in diameter and 65 feet in height.

Blue spruce occurs sparingly between altitudes of 6,800 and 8,500 feet. 'This is one of the largest trees found in the reserve, ranging in height up to 90 feet and in diameter to 30 inches.

Yellow pine is found in this reserve, but it is of very limited occurrence.

There are other species of little commercial value, such as the oneseed juniper, Rocky Mountain juniper and piñon pine.

The aspen is abundant everywhere between altitudes of 6,400 and 10,000 feet, forming dense groves upon old burns.

The timber upon this reserve is of exceedingly poor quality. The stand is everywhere light, the trees are small, branched low down and linotty, and a considerable proportion, 25 per cent to 40 per cent, including all the largest timber, is dead or defective. 
The extent of arable land within the reserve is trifling. It is confined to a few hundred acres, widely seattered about on the lower slopes of the plateans.

But two oceupied ranches were found, although there were many others which had been abandoned either temporarily or permanently.

Owing to the poor quality of the timber in this region, most of that used in the towns on the Denver and Rio Grande Railroad is brought in from outside, and the demand for lumber which this reserve may be called upon to supply is at present, owing to the character of the timber: but very slight.

The cause of the condition of the forest in this reserve is the same as in other parts of the Rocky Mountain region-it is the old story of forest fires, which have raged over it for centuries, injuring or destroying the standing timber and killing the undergrowth. It is only through a cessation of these fires that the region will be afforded an opportunity to be reclothed with timber, and this process will necessarily be a very slow one.

\section{WHITE RIVER FOREST RESERVE.}

The White Rirer Forest Reserve of Colorndo was examined by Mr. George B. Sudworth during the months of July and August, 1898. The reserve is situated in westem Colorado, in the region of high plateaus which flank the Rocky Mountains on the west. It includes the beads of White River. an eastern branch of the Green.

The surface of this reserve is composed of high, level, or rolling plateatus, elevated 10,000 to 12,000 feet above sea level, with the broad deep valleys which separate them. Being in the main a greatly elevated region, it enjoys a rainfall ample for forest growth. The lower valleys of the reserve have a climate which permits of agriculture, but the principal valleys and the summits of the plateaus have an almost arctic climate.

The region as a whole is sparsely timbered. The timber grows in patches and groves of various sizes, from a few acres up to square miles in extent. Altogether, the stand of timber upon it is estimated at 1.300 million feet B. MI. The principal species of value for lumber consint, in the order of their importance, of the following:

Engelmann spruce, which ranges from 19 to 24 inches in diameter and up to 120 feet in height.

Alpine fir, found at the greatest elevations, where it ranges from 18 to 24 inches in diameter.

Lodgepole pine, which is the most abundant, although not the most important tree. Its timber ranges from 8 to 20 inches, and it reaches a height of 75 feet.

Bhe spruce, ranging in diameter from 10 to 24 inches and up to so or 100 feet in height. 
Red fir, 10 to 20 inches in diameter and from 30 to 60 feet high.

Yellow pine, from 1 to 2 feet in diameter and from 60 to 80 feet in height.

In the lower valleys within the reserve are numerous ranches, and scattered about are a number of summer resorts, especially for huntng purposes. There are no villages within the reserve, but there are four post-offices for the accommodation of the ranchmen.

The timber which has been cut upon the reserve is not great in total amount, and has been cut entirely for local consumption and not in any sense for export.

As in all parts of the Rocky Mountain region, the fires have been, in times past and present, very destructive. To this cause is to be attributed the fragmentary character of the forest. If protected from fires, there is no possible doubt that all of this region, with the exception of the lower valleys, would in time be covered with a fairly dense tree growth.

The open lands upon the reserve are used to a large extent for the pasturing of cattle and horses by the ranchmen upon and near the reserve.

There is at present no mining going on upon the reserve.

FLATHEAD FOREST RESERVE, MONTANA.

This reserve was examined by Mr. H. B. Ayres, who devoted about four months to the work. The area examined is approximately 2,160 square miles, including the reserve and a tract of country extending to the westward as far as Tobacco Plains. The area, which lies entirely north of the Great Northern Railway, consists, in general terms, of two mountain ranges, one in the eastern, the other in the western part of the reserve, separated by a broad valley. The easternmost of the two ranges is the eastern range of the Rocky Mountain system in this latitude, facing the plains. Its peaks have an altitude in the neighborhood of the railroad of from 7,000 to 9,000 feet, rising northward, so that at the northern boundary of the country they reach an altitude of 11,000 feet. All the gorges leading out of this range are of glacial origin, and in the upper parts of these gorges glaciers still remain, covering a large part of the region with snow and ice. It is an extremely rugged range, abounding in points of great scenic interest. West of this range is the valley of Flathead River above the lake, which in the south has a width of about 15 miles, narrowing northward toward the boundary. Succeeding this valley on the west is a broken, irregular mountain range, not as high nor as rugged as the eastern range.

Most of this region is drained southward by the Flathead River into Flathead Lake. Smaller portions are drained by the Kíotenai, Saskatchewan, and Missouri rivers. 
Taken as a whole, the region is one of fairly abundant rainfall, although, as it has a wide range in altitude, the rainfall differs greatly in different parts. In the valleys irrigation is probably advisable, if not necessary; while upon the mountains the rainfall is ample for tree growth. Owing to the latitude and the elevation the temperature is low, rendering it doubtful whether agriculture can ever be made profitable within it.

The region is generally lightly timbered. 'This is due not, however, to the climate, which is not unfarorable to tree growth, but to fre¡uent and persistent fires. The merchantable timber in the reserve consists mainly of western larch, red fir, spruce, and yellow pine. 'The entire stand of timber within the reserve, estimating it upon the basis of the present practice in cutting, is only 300 million feet. Measuring it, however, by Eastern standards, Mr. Ayres finds 851 million feet, and in addition to that $3,628,000$ cords of wood suitable for firewood. This amount stands upon an area of 1,942 square miles, learing only 218 square miles reported as not timbered.

It is plain from the above that this reserve can not be regarded ats an important source of timber at present, but rather as a region for the cultivation of timber for future use.

Numerous claims have been taken up in various parts of this reserve, the greater portion of which are apparently abandoned or are oecupied only a small part of the time. Indeed, it appears that only 40 or 50 claims are continuously occupied. 'Ihe probabilities of agriculture in this region are somewhat doubtful, owing to the severity of the climate.

There are no producing mines within the reserve, although many locations have been made upon which assessment work is being done.

\section{BITTERROOT RESERVE (IDAHO PORTION).}

This portion of the Bitteroot Reserve was examined by Mr. I. B. Leiberg, who devoted to it the entire season, commencing early in June and concluding work in the beginning of Oetober. 'The area examined exceeds 5,600 square miles or 3,612,160 acres. 'The surface is made up of great massive spurs from the main divide of the Bitterroot Range, which forms its eastern limit. These spurs trend westward and separate branches of the Clearwater, excepting the southern part, which is drained by Salmon River and short tributaries from the north. The country is excedingly rugged and mountainous, the ralleys being, in the main, narrow, with precipitous walls rising at steep angles. It is an extremely inacessible region, being traversed by very few trails and no wagon roads. The eleration of the region ranges from 3,000 feet in the lowest valleys up to 9,500 feet upon the mountain summits.

But little mining is or has been done within the limits of thereserve; 
a few placers nave been discovered and worked, and some quartz leads have been discovered, but at present the latter are merely prospects.

Agricultural land is very limited in amount, and is distributed in small areas in the narrow valleys upon the west side of the reserve.

There is considerable land suitable for grazing, both in the stream valleys and high up in the mountans. These areas altogether amount to many thousand acres, but collectively are not large in comparison with the entire area of the reserve.

There are at present no stock or sheep pastured within the reserve, except a few owned by ranchmen.

Settlement is confined to a few valleys in the western part of the reserve, and is very limited in amount. The few settlers have no market at present for their products; indeed, the products are limited in range, owing to the severity of the climate.

The rainfall through this entire region is heavy, being probably sufficient in the average year for cultivation without irrigation.

The aspect of the forests is extremely diversified, a feature which is apparently due, in part, to the great range of altitude, and in part to the great prevalence of fires. The region contains a great number of tree species and exhibits a great range in age of trees. Of the $3,612,160$ acres embraced in the region examined, $\mathrm{Mr}$. Leiberg finds that 193,000 acres are naturally treeless. This area is situated mainly upon the higher parts of the mountains, where the ruggedness of the surface precludes tree growth. He finds that within the past seventytive years $1,442,141$ acres have been badly burned, and the remainder of the area, 1,977,016 acres, has been untouched by fire, and is consequently covered with tree growth of considerable size, and therefore of value.

Upon this area he finds $4,899,800,000$ feet B. M. of merchantable timber, consisting of the following species in the proportion given:

Rerl fir - .

Per cent.

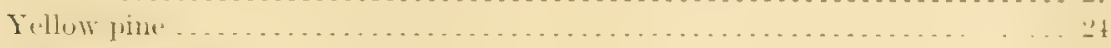

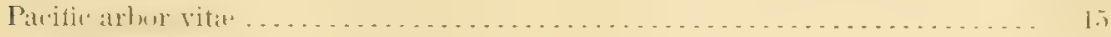

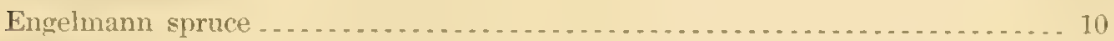

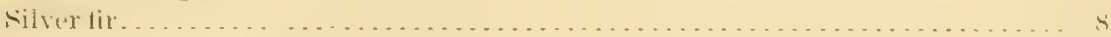

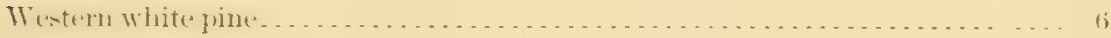

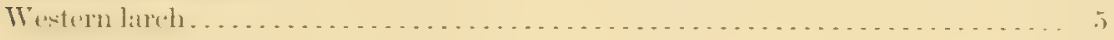

Alpine hemlock . . . . . . . . . . . . . . . . . . . .

Lomberente jine.

It must not be understood from the above table that the total amount of lodgepole pine nor the area covered by it is in proportion to the amount here reported as merchantable. On the contrary, this is the most abundant tree in the reserve and occupies by far the largest area, especially among the young growth.

The average stand of timber upon the areas occupied by merchant- 
able timber is about 2,500 feet per acre. The stand, howerer, shows wide rariations with different areas and different species, ranging as high, in some localities, as 100,000 feet per acre over small areas.

\section{FOREST CONDITIONS AND STANDING TIMBER OF WASHINGTON.}

In my last report I published a tabular statement, by counties, of the standing timber of Washington, as estimated by cruisers, under the lumber practice prevailing in the State, and detailed statements regarding land classitication, the stand of timber, and the amounts of various species in the western counties.

During the past winter the work of collecting cruisings and of preparing detailed estimates has been finished for the entire State, and the results are herewith presented, together with maps showing the classification of lands and the distribution of timber. (Pls. II-VII.)

With the exception of the redwood forests of California, the forests of western Washington are among the densest, heaviest, and most continuous in the United States. Except for a few prairie openings, and except where removed by fire or the ax, they formerly covered the country as a thick mantle from a line high up on the Cascade Range westward to the shores of the Pacific. In all this region only the Olympics rear a few summits above the forests. Not only are the forests dense orerhead, but the undergrowth is dense and tangled beneath. The trees are large, reaching 12 to 15 feet in diameter and 250 feet in height, with clear trunks for 100 or more feet. 'The timber is mainly red or vellow fir (P'seudotsuga taxifolia), mingled with spruce, hemlock, and cedar.

The amount of standing timber in this region has long been a matier of interest, and many wild guesses have been hazarded. As usual in such cases, most of them have been far above the truth. With no data on which to base an estimate the tendency is to exaggerate.

To obtain an approximation to the true amount, statisties derired from cruisings recently made have been obtained from all parts of the State, and especially from the heavily timbered portion lying west of the Cascade Range. The sources of this information are as follows:

The Northern Pacific Railway Company, which has made most elaborate cruisings of that part of its land grant situated west of the Cascade Range, has, with great liberality, through its western land agent, $M r$. Thomas Cooper, furnished an abstract of all the information in its possession regarding timber lands, including not only the statistics of standing timber, but maps showing the areas at present forested, those naturally unforested, those which have been cut over, and those which have been burned. These statistics have been compiled and the maps have been prepared hy Messi's. John M. Rankine and George H. Plummer, of the Northern Pacific Railway oftice. The commissioner of the State land office has fumished alsstracts of all cruisings made 



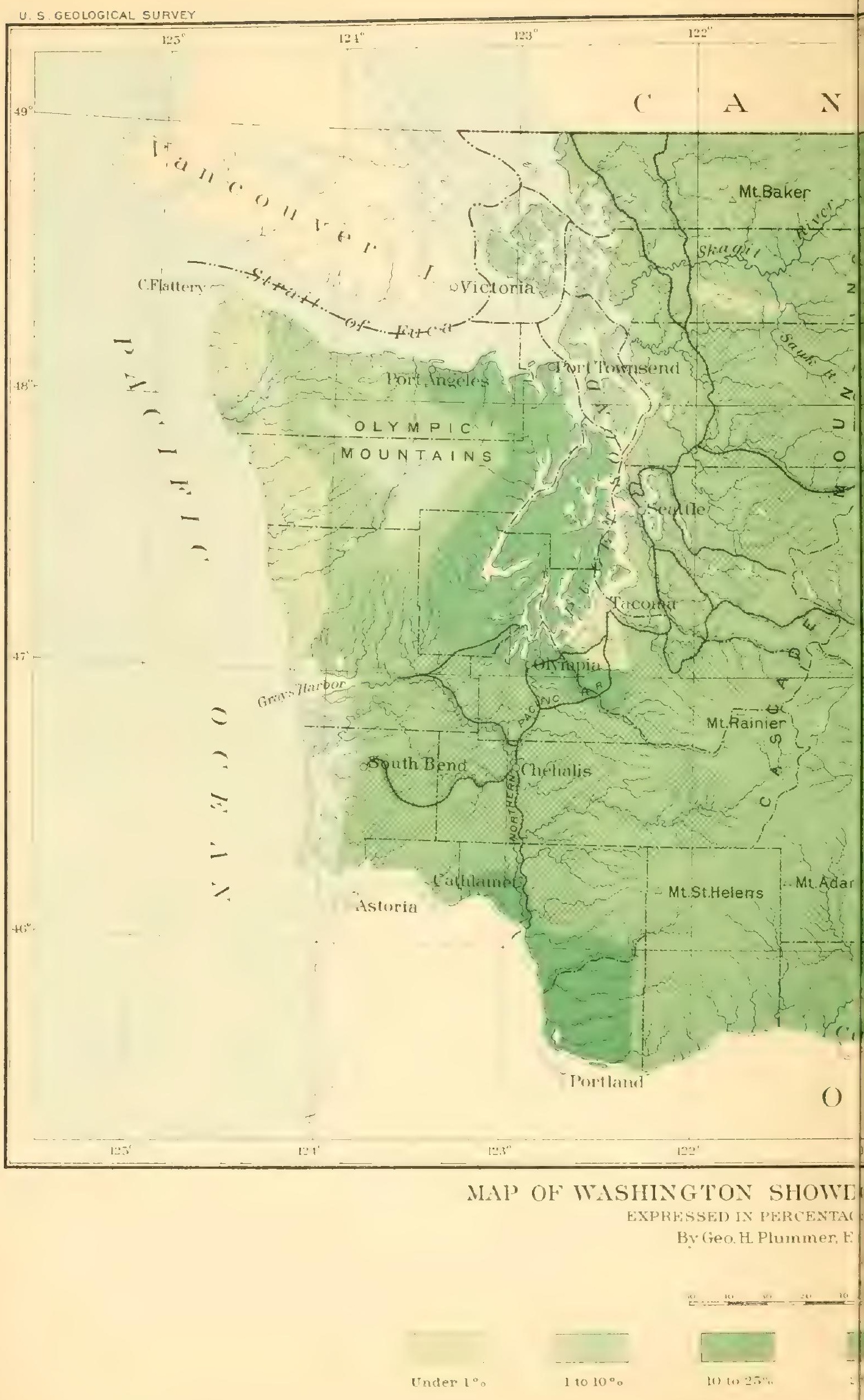




$120^{\circ} \quad 119^{\circ} \quad 118^{\circ}$

117

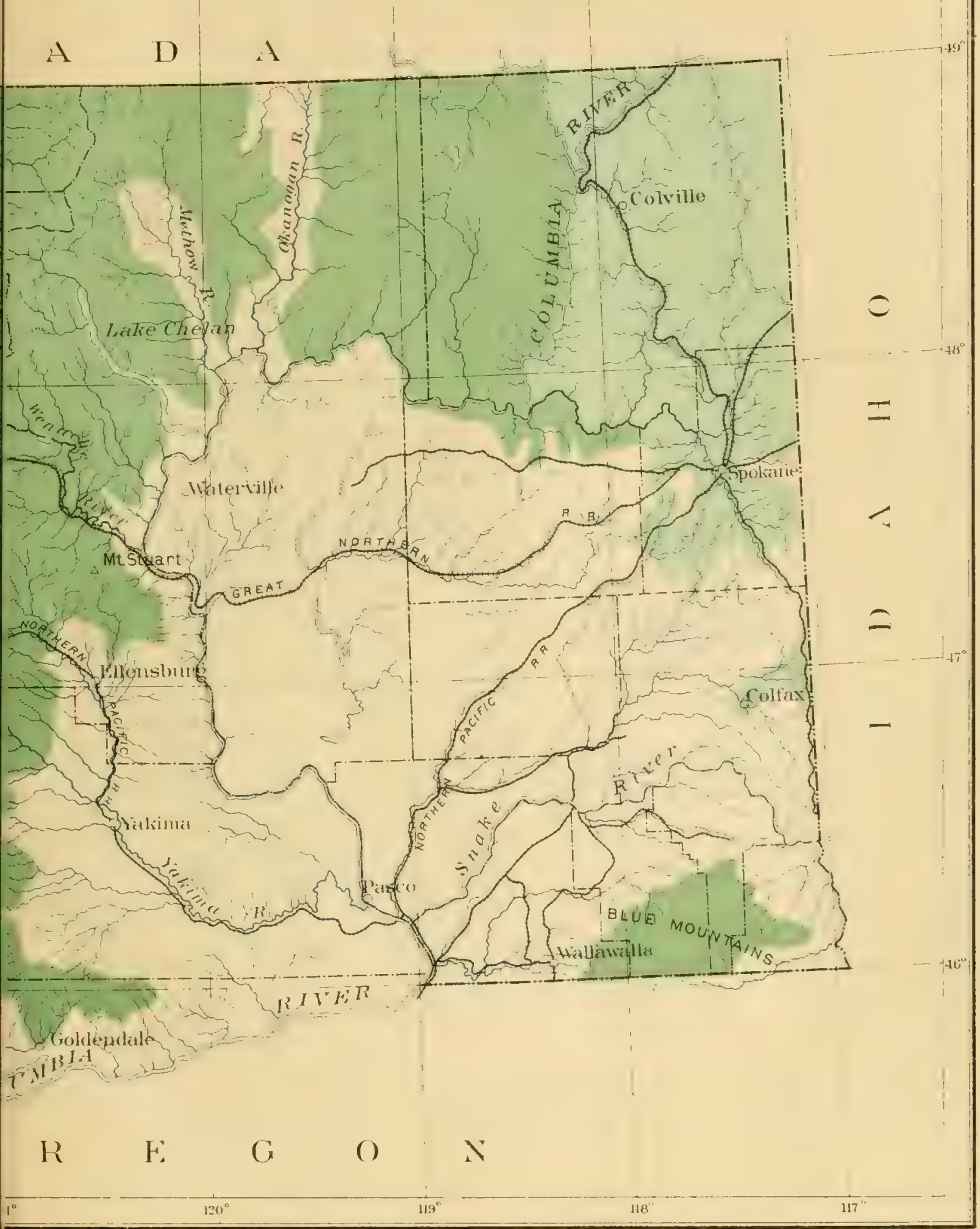

; 'THE DISTRIBUTION OF RFD FIR OF THE TOTAL FOREST AREA

'lummer and J. H. Rankine

98

ale 

for the selection of lands for the State. Besides the abore, sereral lumber companies nd owners of timber land have placed their information at the disposal of this oftice.

The collection of data and preparation of estimates for the counties east of the erest of the Cascade Range has been done by Mr. Fred G. Plummer, who has devoted the winter months of 1898-99 to this Work.

Altogether, cruf ings of more than two million acres have been collected. These are scattered widely over the State and represent thoroughly well the stand of timber under all the different conditions of rainfall, temperature, soil, slope exposure, relief, and altitude.

The other factor necessary for obtaining the total stand of timber, the area of merchantable timber, has been obtained from the same sources in the greatest detail, and with this the areas which have been logged and which e been burned in recent years.

In connection with data regarding the stand of timber, its distribution as to species has been obtained, the classification being that recognized by lumb rmen.

From these data we total amount of timber in the State, under the $W$ ashington lumbering practice, is estimated at 114,778 million feet B. M. Of this amount more than nine-tenths, or 103,504 million feet, are west of the crest of the Cascade Range, the remainder, 11,274 million feet, being upon its eastern slope and in the northern and eastern portions of the ate. This total is less than half that estimated as standine in Oregon, a fact which I explain by the following considerations :

First, the area of merchantable timber is by no means so great in Washington as in Oregon. While the wooded areas do not difler materially, that of $C$ egon being 54,300 square miles and that of Washington 47,700 square miles, a much larger proportion of the wooded area of Oregon is occupied by timber of merchantable size and species. For instance, the Cascade Range in Washington is much broader than in Oregon and at much greater altitude, thus cutting out on this account a larger part of the wooded area. The Olympic Mountains also subtract another large part of the wooded area.

Second, the lumber industry of Washington has been, especially in recent years, much more important than in Oregon, and consequently a larger area has been cut over. In 1890 the cut of Washington was double that of Oregon.

Third, although the Coast Ranges of Oregon have suffered greatly from fires, the State as a whole, and especially the western portion. of it, has not suffered by any means as severely from this source of destruction as has Washirgton, probably owing to the fact that lumbering has not been as active.

The State of Washington is naturally divided into two parts, which 
differ from one another widely in respect to timber growth. The line of division is the crest of the Cascade Range, rumning from the north to the south line of the State. West of it the country is heavily forested, or was before lumbering operations commenced. In this part of the State the areas naturally deroid of timber are few and small and altogether trifling in proportion to the total area. East of it the land is mainly without timber, and where timber exists it is sparse and its quality is inferior.

Moreover, there is a great difference in the species. West of the Cascade Range the prevailing species, which forms nearly two-thirds of the entire forest, is red or yellow fir. 'This, with cedar, hemlock, and spruce, compose the entire forest. Fir is found in almost all parts of this region, and throughout the Sound Valley little of any. other species is found, the forests being almost pure fir. East of the Cascade Range the forest consists mainly of pine, principally yellow pine, though in the northeast corner of the State a little white pine is intermingled. Red fir is found scattered through the pine forests in considerable proportion, and in the northeastern part of the state larch is abundant. Small proportions of hemlock and cedar are also found, and a trifling amount of spruce and oak.

The following table gives the stand of timber of the species recognized by the lumbermen, in thousands of feet, board measure, with the percentage which each bears to the total amount:

Standing timber in Washington.

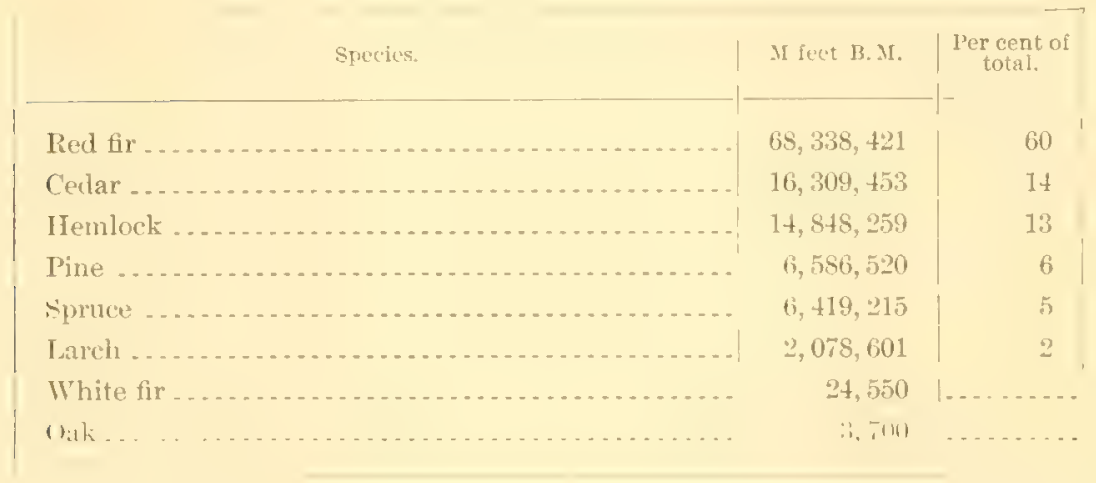

Dividing the State into the two parts above given, the following tables show the distribution of these species in these two sections, with the percentage which each bear's to the total forest of that section: 



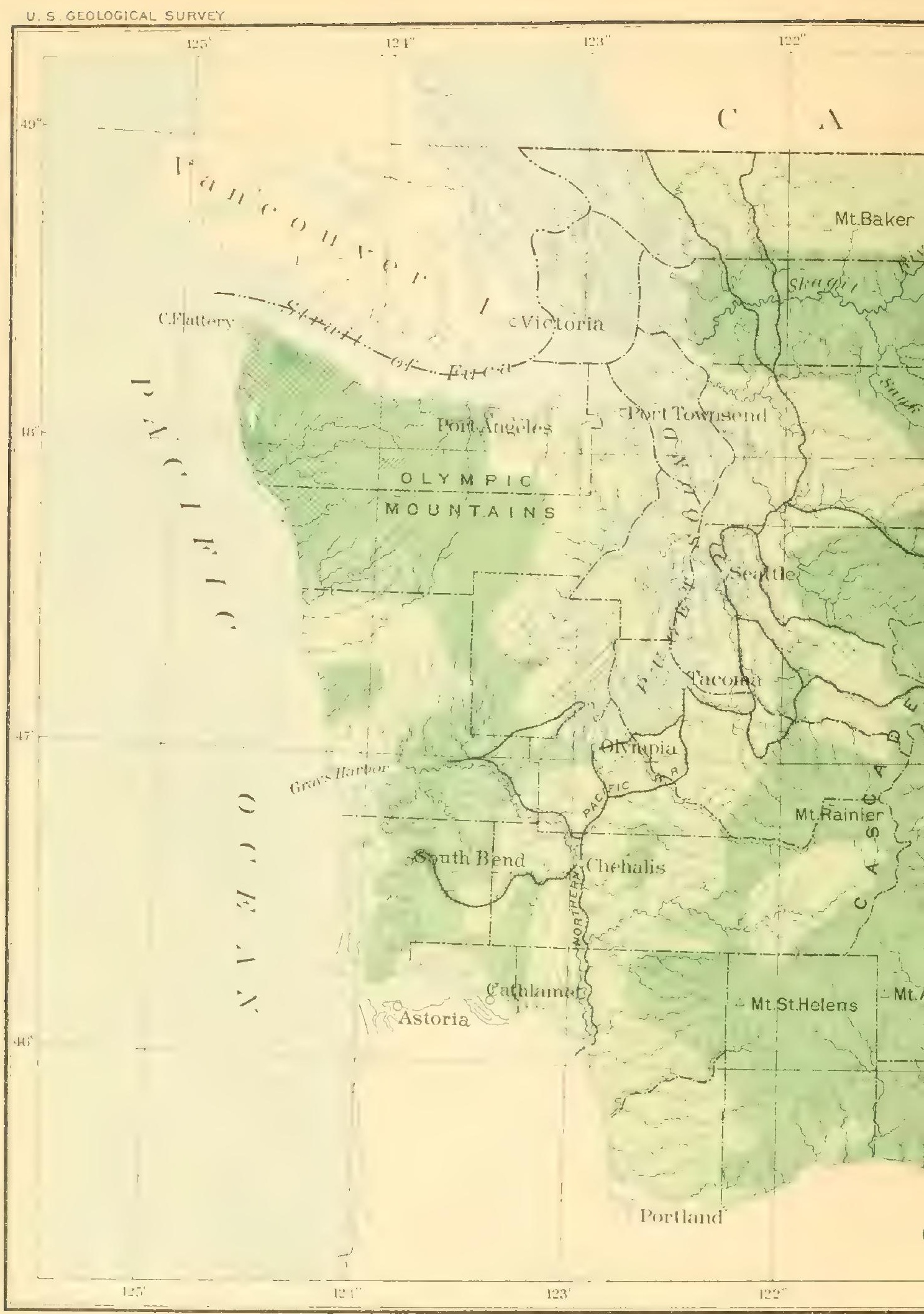

MAP OF WASHINGTON SHOW EXPRESSED IN PERCE By Geo. H. Plumme

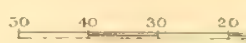




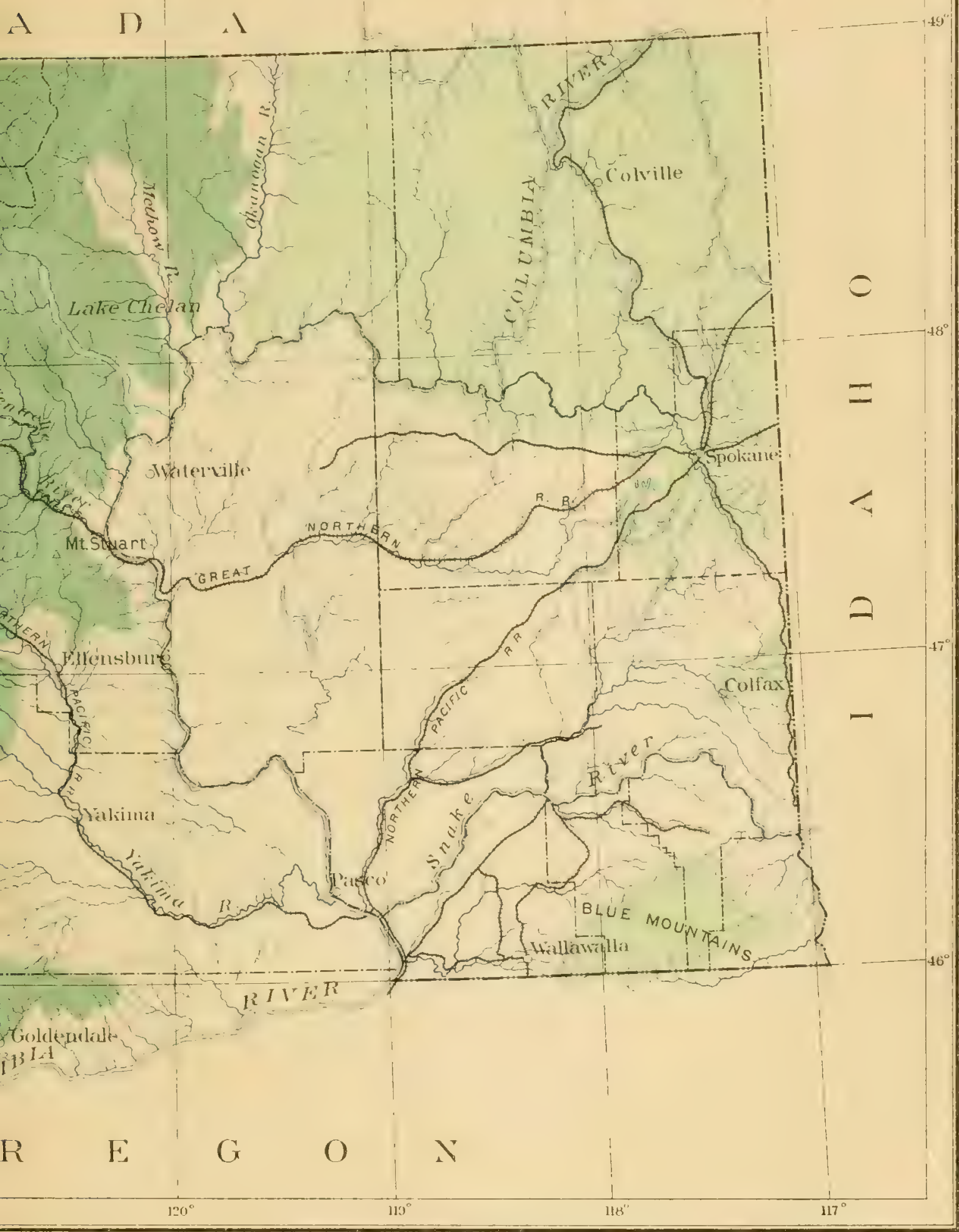

E DISTRIBUTION OF HEMTAOCK

THE TOTAL FOREST AREA

mer and J.H. Rankine 

Sicuting timber in vestern Tashington.

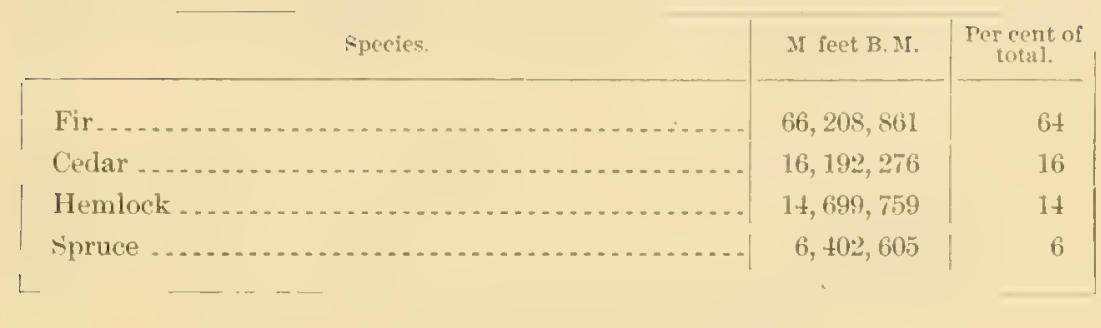

Standing timber in etatern IVashington.

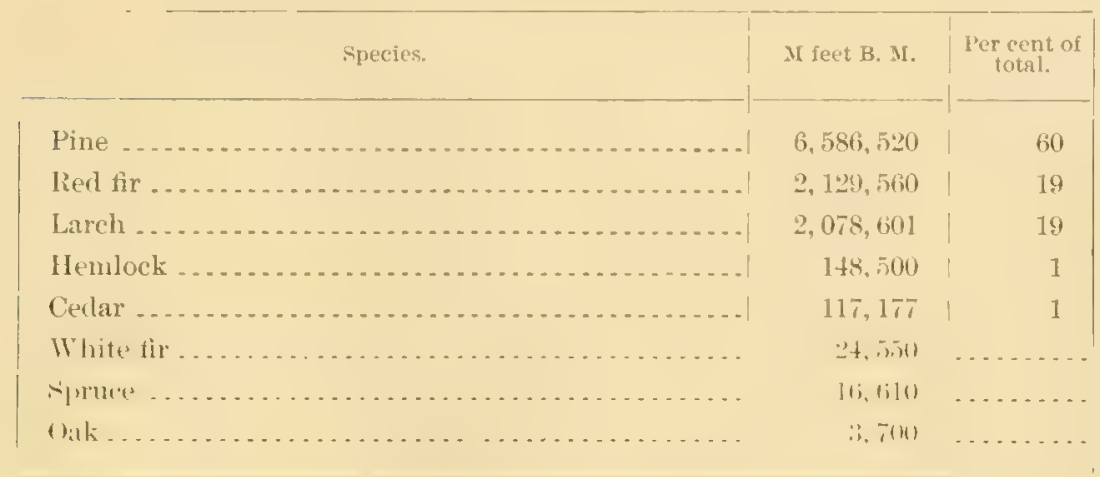

The above figures do not add up to the total given for this part of the State, owing to the fact that a few million fect were not classified by the cruisers.

The table on the next page gives the estimated amount of merchantable timber in each county, in thousands of feet B. M., as at present estimated by lumbermen. If it were cut under the practice which prevails at present, these figures represent a close approximation to the amount which would be realized. There is no question, however, that as in the case of the eastern white pine, a much larger amount will ultimately be realized, for several reasons:

First, the standard will certainly be lowered, so that instead of utilizing only one-third of the tree, two-thirds may be used, and many small trees now destroyed by fire in the culled areas will be cut; second, species not now used may come into the market; third, areas now considered inaccessible will serve as sources of supply; fourth, the new growth on cut and burned areas will reach merchantable size long before the old growth is exhausted.

In illustration of the difference between the supply as viewed by the Washington lumbermen and the actual amount, take the figures given by Mr. Ayres in his report on the western part of the Washington Reserve. Under Washington practice he found but 400 million feet in that area consisting of red fir. But under the Minnesota practice, by which the contents of all species is estimated, without regard to acces- 
sibility, he found not less than 14,400 million feet. This is, of course, an extreme case, but it is probably paralleled throughout the Cascade Range and in the Olympics.

Merchantable timber in the State of Wrashington, by counties.

\begin{tabular}{|c|c|c|c|}
\hline County. & M feet B. M. & County. & M feet B. M. \\
\hline Asotin.... & 81 & Lincoln. & 14 \\
\hline Chehalis.. & 18,579 & Mason . . . . . & 2,091 \\
\hline Clallam .............. & 9,072 & Okanogan ...... & 2,660 \\
\hline Clarke ............... & 2,342 & Pacitic ...... & 7,813 \\
\hline Columbia............ & 243 & Pierce........ & 6,520 \\
\hline Corvlitz............. & 5,216 & Skagit ............... & 10,362 \\
\hline Douglas .............. & 31 & Skamania_............ & 4,661 \\
\hline Ferry ................. & 1,667 & Snohomish .... & 7,709 \\
\hline Garfield .............. & 170 & Spokane............... & 766 \\
\hline Island . . . . . . . . . . . . . . & 430 & stevens............... & 2,702 \\
\hline Jefferson .............. & 4,230 & Thurston ............. & 2,787 \\
\hline King .................. & $7,6+4$ & Wahkiakum ........... - & 2,974 \\
\hline Kitsap ............. & 1,141 & Wallawalla .......... & 5 \\
\hline Kittitas ........... & 1,260 & Whatcom.............. & 1,346 \\
\hline Kilickitat .. & 743 & Whitman... & 35 \\
\hline Lewis..... & 8,586 & Yakima _............ & 893 \\
\hline
\end{tabular}

The counties omitted contain no merchintable timber.

Average stand of timber per nere on timbered areas.

\begin{tabular}{|c|c|c|c|}
\hline County. & Feet B. M. & County. & Feet B. M. \\
\hline Arotin. ............. & 1,200 & I.incoln ....... & 300 \\
\hline Chehalis.............. & 21,300 & Mason... & 5,600 \\
\hline Clallam ............. & 15,700 & Okanogan . & 1,100 \\
\hline Clarke ............. & 19,000 & P'acitic ............ & 16,300 \\
\hline Columbia...... & 1,700 & Pierce................ & 18,0000 \\
\hline Cowlitz............... & 20,400 & Skagit...... & 28,000 \\
\hline Douglas ... & 1,000 & Skamania............. & $1 \vec{i}, 0+10$ \\
\hline Ferry ................... & 1,200 & Snohomish ........... & 19,000 \\
\hline Garfield ............. & 2,000 & Spokane......... & 2,300 \\
\hline Jefferson ............ & 15,300 & Stevens..... & 1,100 \\
\hline King ....... & 20,500 & Thurston ............. & $11,0,0$ \\
\hline Kitsap ........ & 9,000 & Wahkiakum..... & 27,000 \\
\hline Kittitas............. & 1,000 & Whatcom............. & 24,000 \\
\hline Klickitat ...... & 1,400 & Yakima... & 1,900 \\
\hline Lewis ................ & 16,500 & & \\
\hline
\end{tabular}





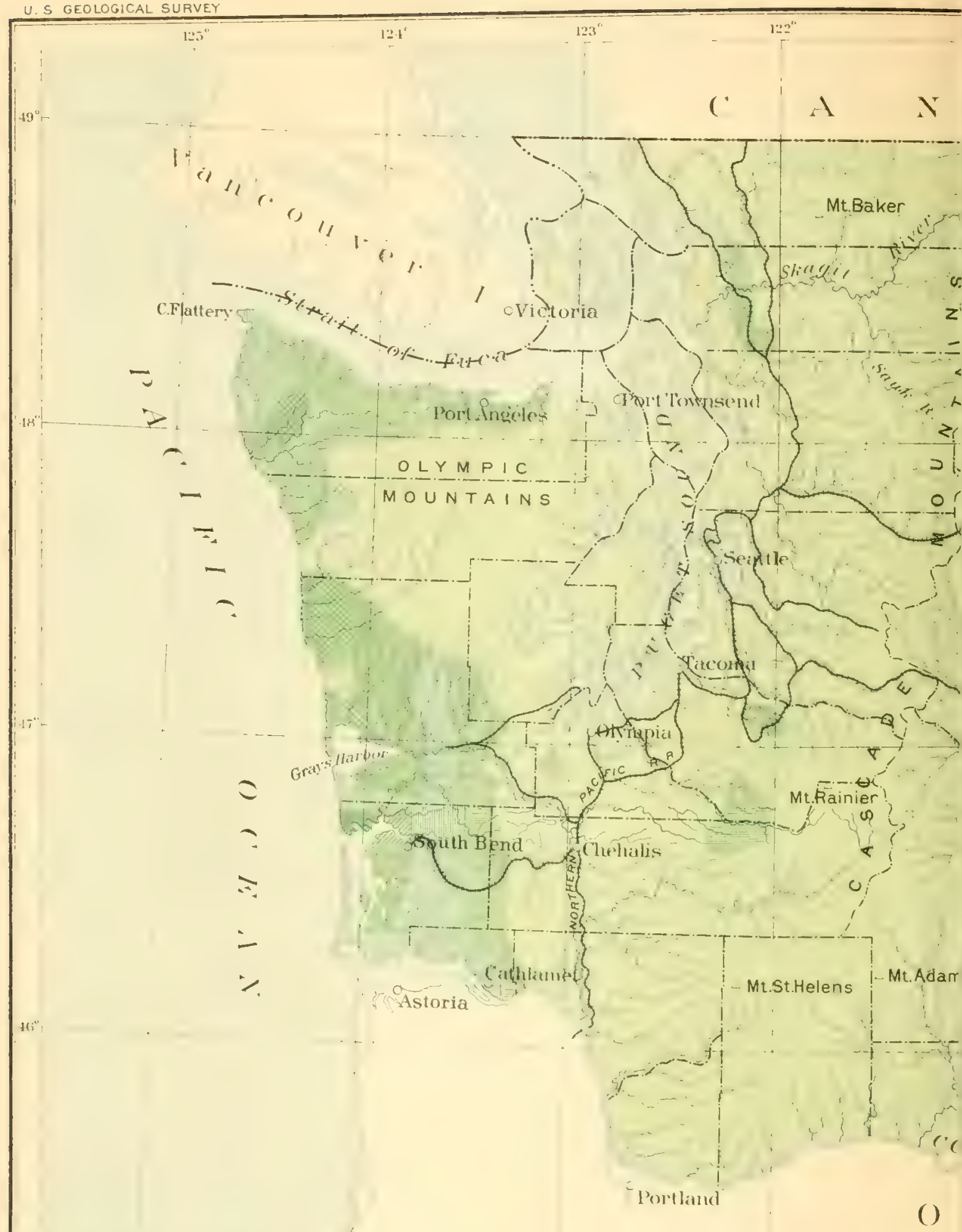



The stand is heariest in Skagit County, near the northern boundary. The next heariest is Wahkiakum, in the southwest, near Columbia River. In western Washington the average stand is 18,000 feet; in eastern Washington it is but 1,200 feet B. M.

The entire area of Washington is 66,880 square miles. Of this 23,165 square miles are covered with merchantable timber, or 36 per cent of its area. Only one-half of the wooded area of the State is regarded as containing merchantable timber under present lumbering practice.

The entire area of the nineteen counties of western Washington is 24,906 square miles. Of this area but little more than one-third, or 9,039 square miles, is regarded as containing merchantable timber. Besides this, an area of 3,025 square miles has already been logged; a much greater area, 3,614 square miles, of merchantable timber has been burned, besides an area of 700 square miles in the mountains not containing merchantable timber. In other words, out of an area of 15,858 square miles formerly covered with merchantable timber, 20 per cent, or one-fifth, has been cut; $22 \frac{1}{2}$ per cent has been destroyed by fire, and the remainder, $57 \frac{\mathrm{x}}{\mathrm{z}}$ per cent, is still covered with standing timber. In this entire area there are only 833 square miles which are naturally timberless.

If we assume that the logged area contained on an average the same amount of timber per acre as is still standing in other areas, it appears that since lumbering began in this region there have been cut from it 36,000 million feet B. M.

If we make the same assumption regarding the burned area, it appears that there has been destroyed by fire, without the least benefit to the world, the enormous amount of 40,000 million feet B. M. of lumber. Anyone who has passed the late summer and early fall in this State realizes the enormous destruction which takes place annually at this season. There are fires everywhere, and for weeks at a time the smoke from them lies as dense as the fog on the New England coast.

These are impressive facts. In less than a generation more than two-fifths of the timber in one of the richest timber regions on this continent has been destroyed, and of that destruction more than half has been caused by fire. Nearly two years' supply of lumber for the United States has been thus destroyed. Assuming that the timber thus destroyed would, if standing now, have a value of 75 cents per thousand feet, it appears that not less than $\$ 30,000,000$ worth has thus gone up in smoke - a dead loss to the people of the State.

In eastern Washington, out of an entire area of 41,928 square miles, 14,126 square miles only are now covered with merchantable timber, or only one-third of the area. Of the area at one time timbered, 1,385 square miles have been cut over and 241 square miles have been burnt. These figures present a strong contrast with similar figures 20 GEOL, PT $5-2$ 
for western Washington, both in respect to cut and burnt areas. The reason for it lies in the fact that in this part of the State the cutting is done only for local consumption and never for export, and in these open sparse forests of yellow pine fires do not run freely or cause much damage.

The distribution of the different species recognized as lumber in Washington is represented on Pls. III to VII and is seen to follow a few definite and simple laws. The tints represent the proportion which each species bears to the entire forest. 'The map showing the distribution of red fir shows that upon the west shores of Puget Sound the forest is practically pure fir, and that southward as far as Columbia River, throughout the ralley of the eastern slope of the Cascade Range, more than three-fourths of the forest is composed of this species. The proportion diminishes as the Pacific coast is approached, and upon the coast and in an area or belt extending from 10 to 25 miles inland, there is practically no red fir to be found. On the east coast of Puget Sound and southward, between one-half and three-fourths of the forest is composed of fir. The proportion increases somewhat as we recede from the sound, but at an altitude of about 3,000 feet in the Cascade Range the fir disappears.

The distribution of spruce is expressed on the map in a similar manner and is equally characteristic. There is practically no spruce on the Cascade Range or on the eastern slopes of the Coast Ranges. It is most abundant immediately upon the Pacific coast and diminishes thence inland.

Of cedar there is scarcely any to be found upon the islands and upon the west coast of Puget Sound, and but very little in the valley to the southward. It increases westward toward the coast and reaches a maximum immediately on the coast. The east coast of Pugret Sound contains a large proportion of cedar, ranging from one-fourth to onehalf of the forests, and that proportion diminishes as we ascend the Cascade Range.

Hemlock is almost entirely wanting upon both shores of Puget Sound and in the valley to the south. It increases westward and forms a quite noticeable proportion of the forests in the Coast Ranges and in the northwestern part of the Olympic Peninsula. It increases also as we ascend the Cascade Range, its halbitat extending nearly to timber" line.

ADAMS COUNTY.

This county lies in the southeastern part of the State. Its surface consists of a broadly undulating plateau of basalt, containing few stream courses but many conlees.

The county contains no timber whatever, excepting strips of willows, alder's, and aspen along the few streams. 



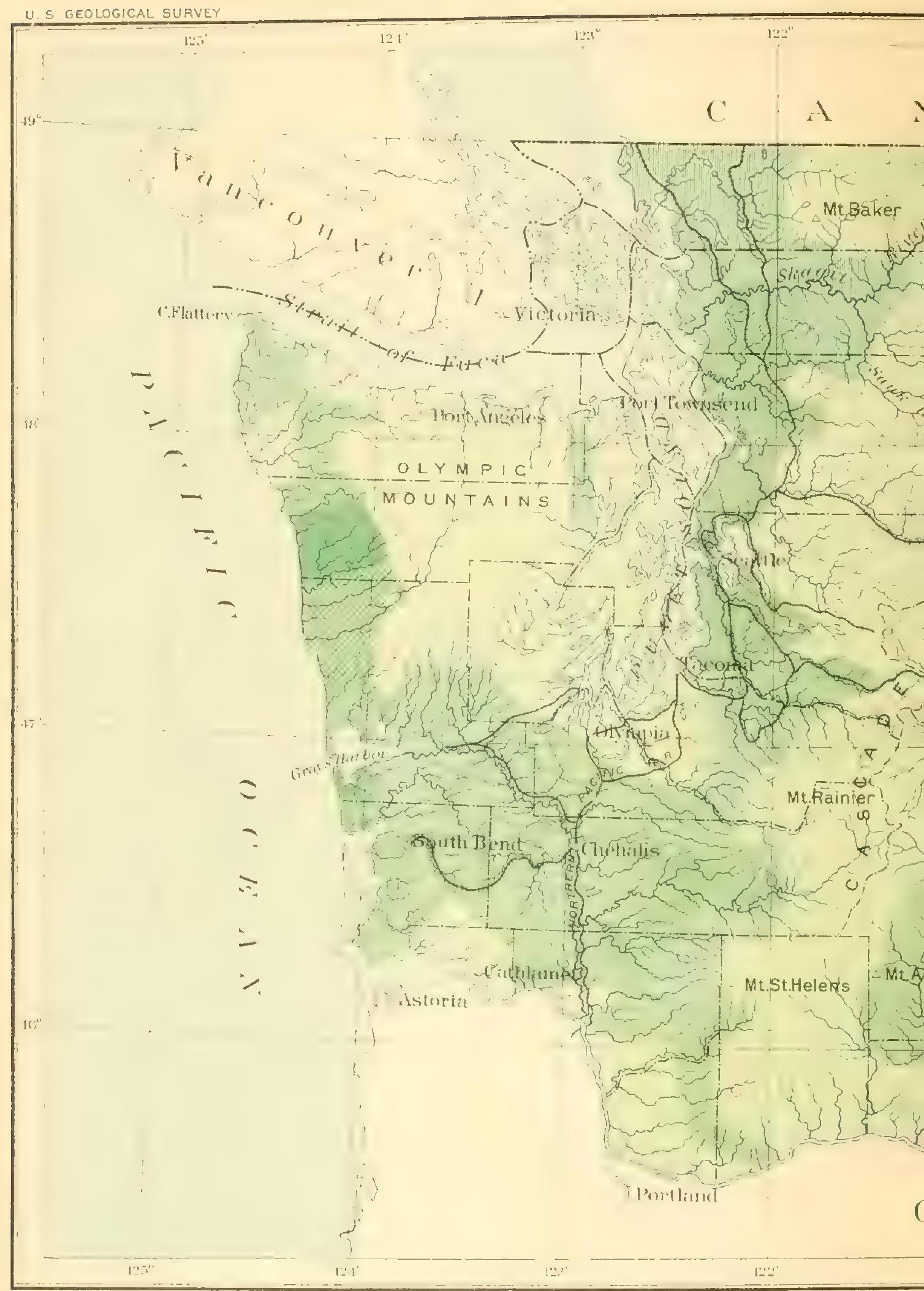

MAP OF WASHINGTON SHO EXPRESSED IN PERCEN By Geo. H. Plumme 


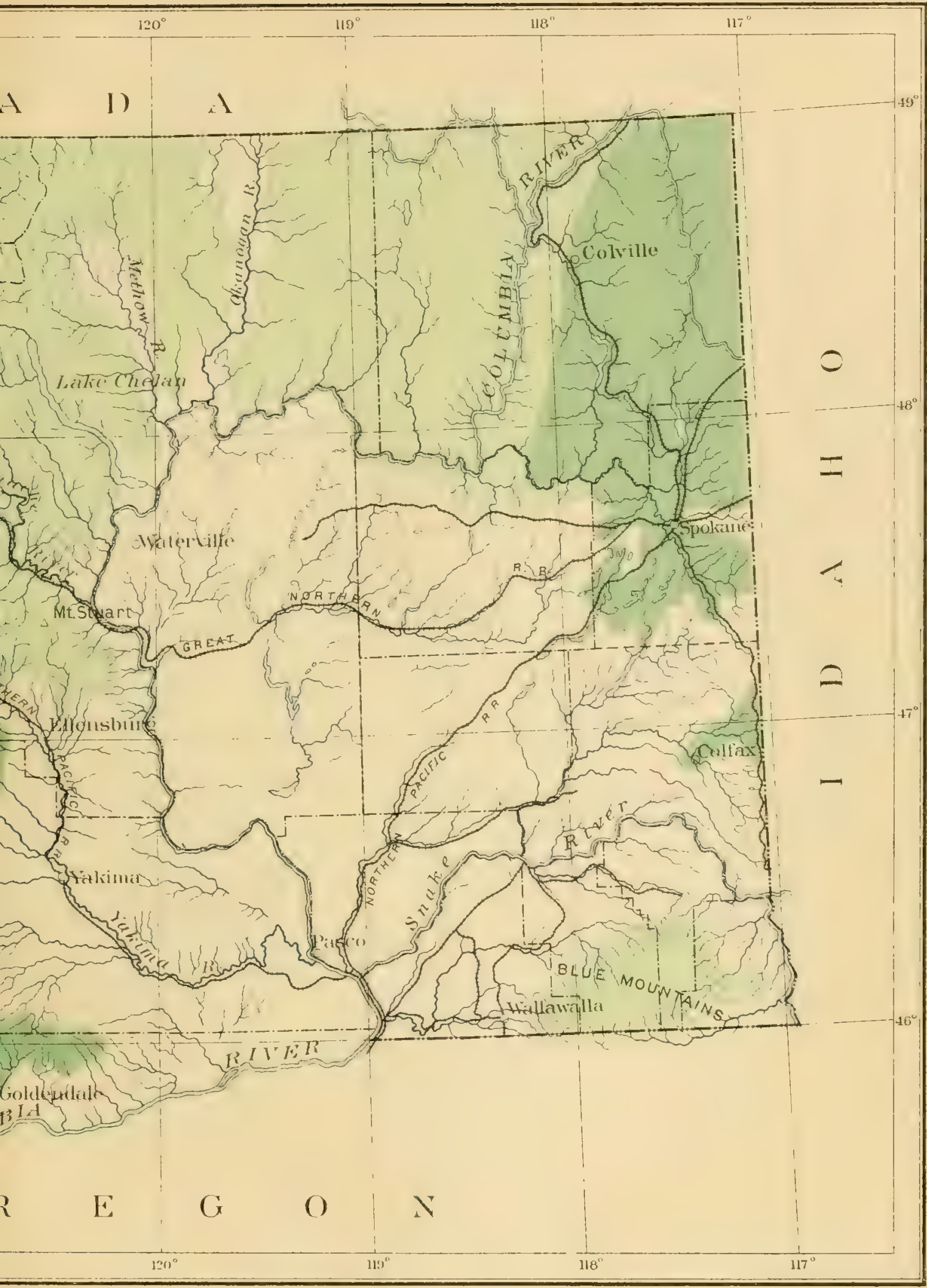

HE DISTRIBUTION OF CEDAR

HE TOTAL FOREST AREA

her and J.H. Rankine 

ASOTIN COUNTY.

This is the southeasternmost county of the State. It consists mainly of the undulating, timberless, basalt plain of Snake River, but into its western edge extends the end of a spur from the Blue Mountains which bears some timber.

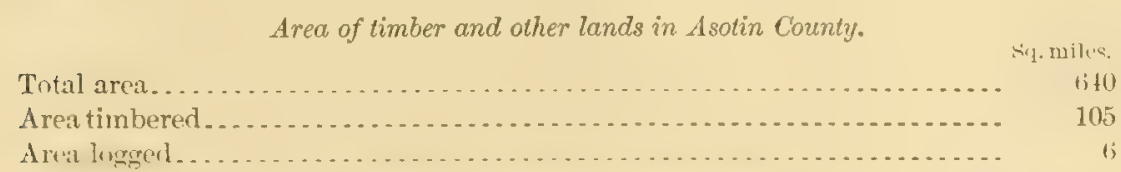

Estimate of timbler in Astin ('inlut!l.

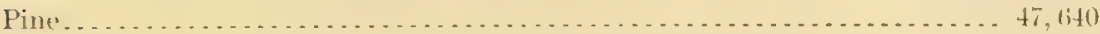

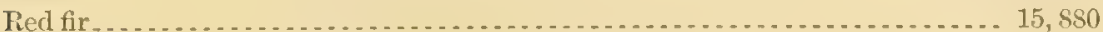

Iarih .........................................

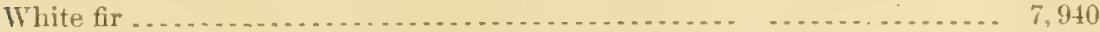

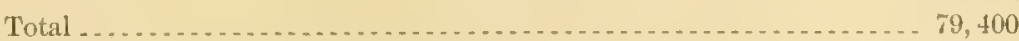

Average stand per acre in feet B. M. . . . . . . . . . . . . . . . . . 200

Besides the above there is upon the cut area a small amount, estimated at 2 million feet, still standing, which, added to the above estimate, gives a total of $81,400,000$ feet for the county.

CHEHALIS COUNTY.

This county borders upon the Pacific Ocean, and on the north extends far up into the Olympic Mountains. The northern portion of the county is high and rugged and contains little or no merchantable timber, and in other portions there are numerous small prairie tracts. Aside from these areas the county was originally heavily forested, mainly with fir in the interior and with spruce and cedar upon the coast. There have been few fires in this county, and the burned area is trifing. Lumbering has, however, been carried on extensively upon the streams flowing into Grays Harbor, and especially upon Chehalis River, nearly one-tenth of the timbered area of the county having been denuded of its forests.

Area of timbered and other lands in Chehalis County, Washington.

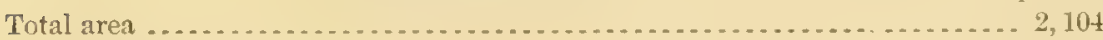

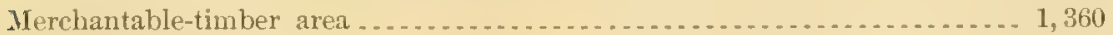

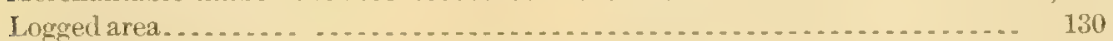

Xiturally bate areat . . . . . . . . . . . . . . . . . . . . . . . . .

Fiundert areat . . . . . . . . . . . . . . . . . . . . . . . . . . . . . . . .

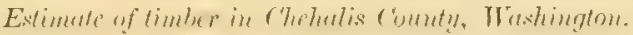

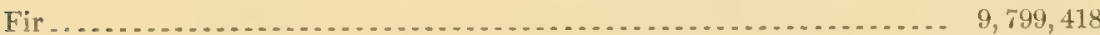

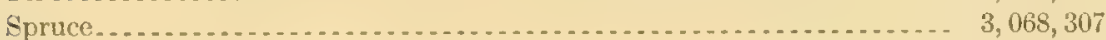

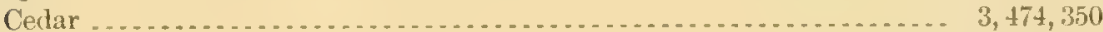

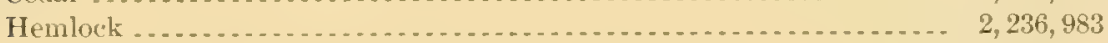

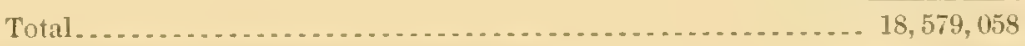

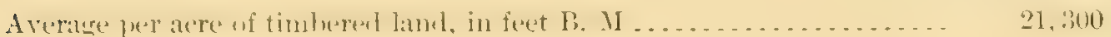




\section{CLALLAM COUNTY.}

This county occupies the northern part of the Olympic Peninsula. The southern portion of the county comprises a part of the Olympic Mountains, and is not regarded as containing any timber of present merchantable value. The remainder of the county was heavily forested, but the ax has made inroads in these forests along the shores of Puget Sound as far west as Crescent Bay, and fires have extended inland from these cuttings to the mountains, destroying considerable areas of timber. The western part of the county is still an unbroken forest.

The forests of this county are remarkable in the fact that they contain a large proportion of hemlock, the amount of this tree being greater than that of the red fir.

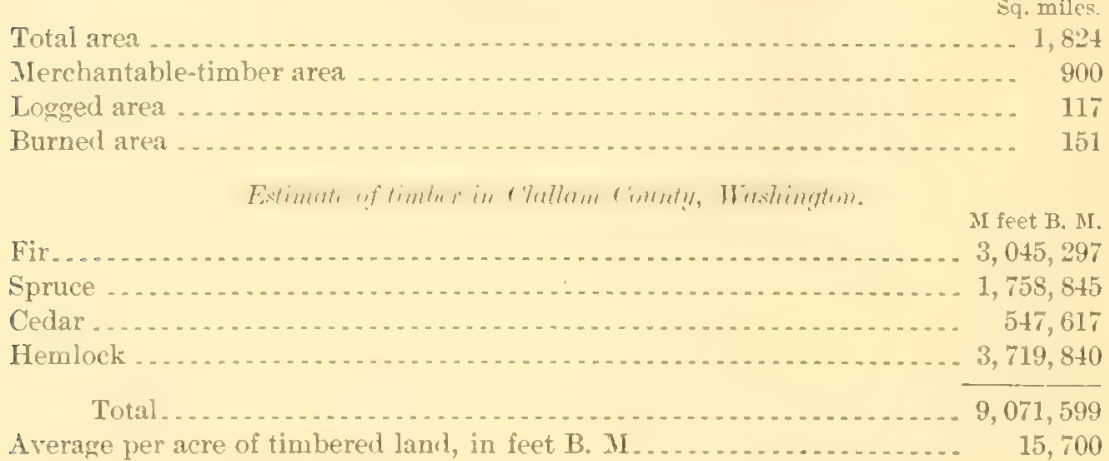

CLARKE COUNTT.

This county lies in the southwestern part of the State, bordering on the south and west upon Columbia River. Originally it was entirely corered. with heary forests with the exception of a few small prairie tracts.

But little timber has been cut in the county, lumbering being principally confined to the line of the Portland, Vancouver and Yakima Railroad, and, on the other hand, the timber upon two-thirds of the county has been destroyed by fire, the burned areas lying principally in the southern and western parts of the county, leaving large bodies of forest in the eastern part.

The forest consists almost exclusively of fir, there being very little cedar and hemlock, and no spruce whatever.

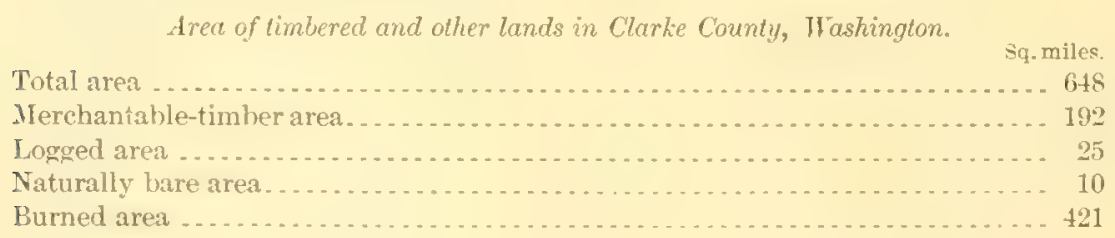





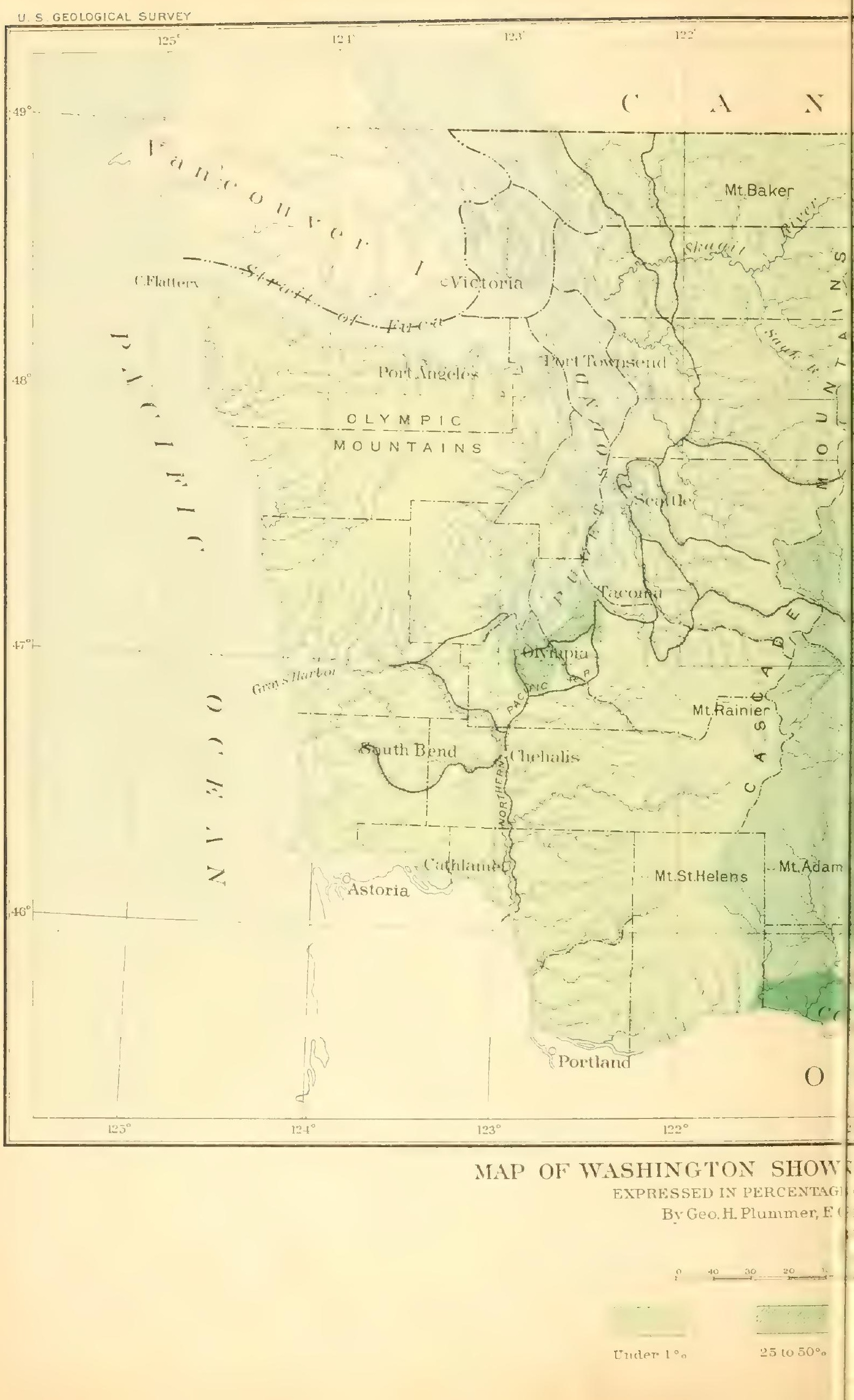




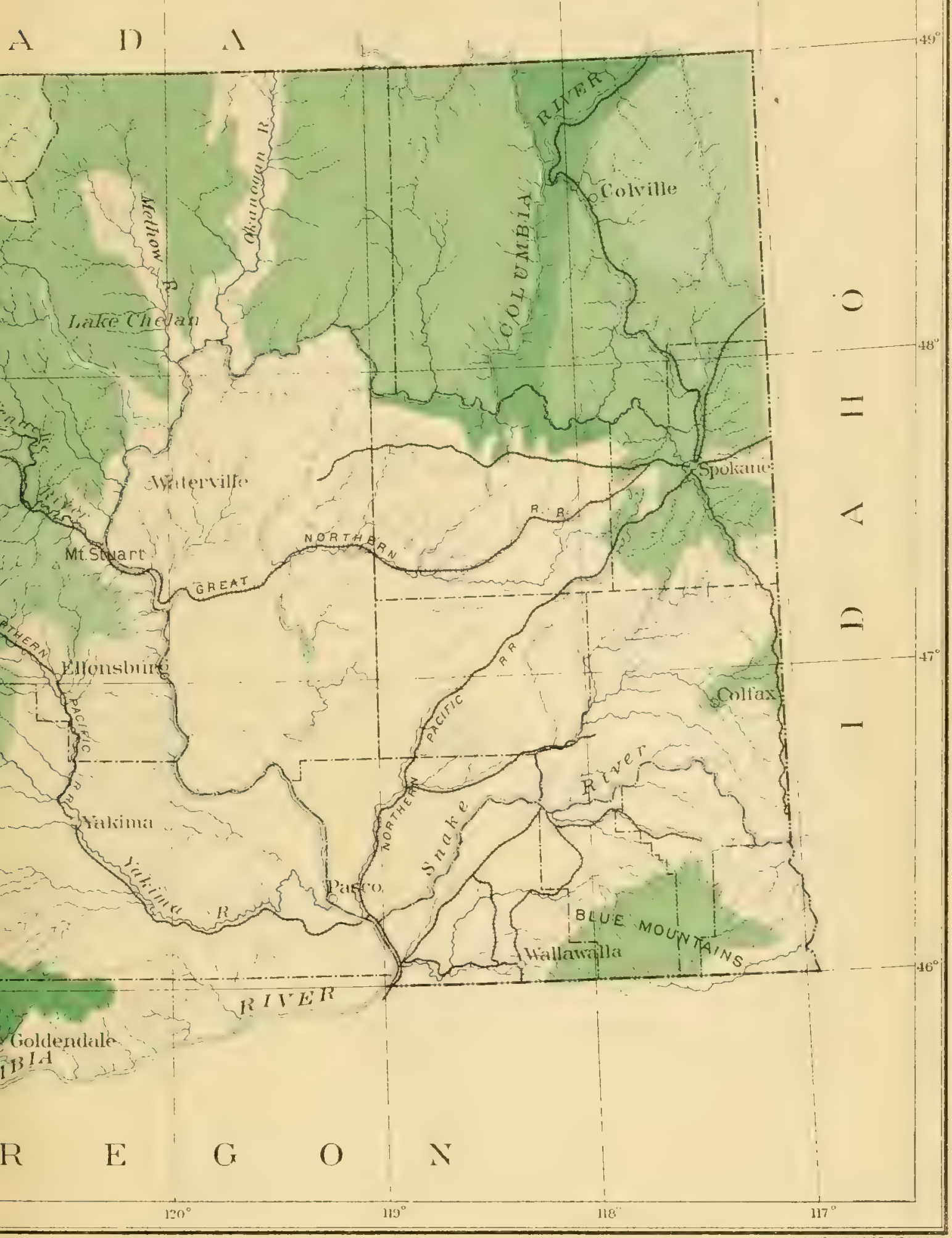

THE DISTRIBUTION OF PNE

THE TOTAL FOREST AREA

mer and J.H. Rankine 

with fine merchantable forests. Fires have, however, been extremely disastrous in this county, destroying the timber on large areas, particularly in the eastern and sonthern parts of the county. Lumbermg has been carried on along Columbia and Cowlitz rivers, and considerable areas have thus been denuded; but this bears little comparison to the areas denuded by fire, which comprise fully one-half of the portion originally covered by merchantable forests.

Area of timbered and other lands in Coulitz County, Tashington.

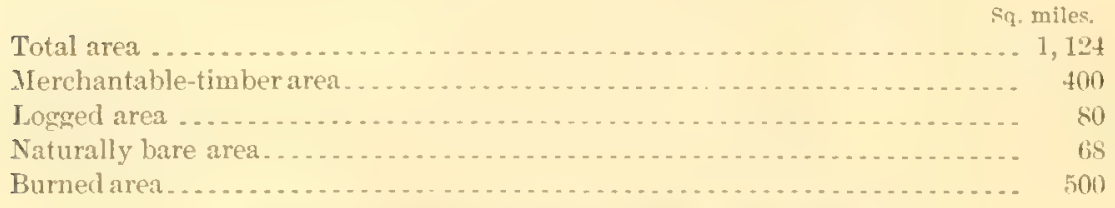

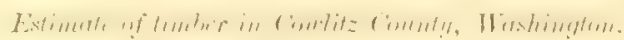

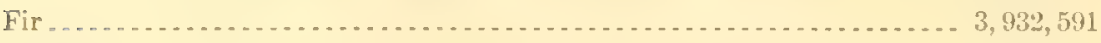

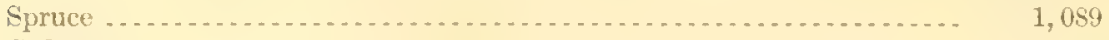

Cedar .............................................................. 627,571

Hemlock .........

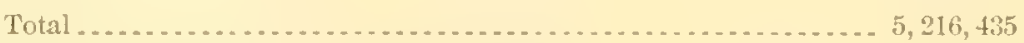

Average per acre of timbered land, in feet B. M............... 20,400

DOUGLAS COUNTY.

This county lies a little east of the center of the state, its area being comprised entirely within the Great Plains of the Columbia. It is bordered upon the north and west by Columbia River, flowing in a deep and narrow valley. The surface of the county is broadly undulating, consisting of a basalt plateau, intersected by coulees and stream cunyons. It is almost entirely treeless, only about 1 per cent of its area being timbered, the timbered areas lying in narrow strips on the edge of the plateau near Columbia River. Along Columbia River, between Wenache and Virginia, are a few scattered pines and fir.

Area of timber and other lands in Douglas County, Washington.

Sq. miles.

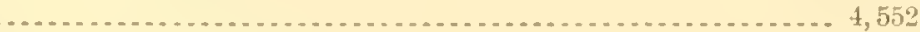

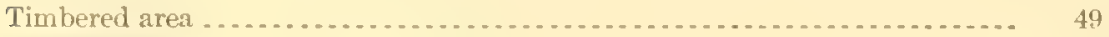

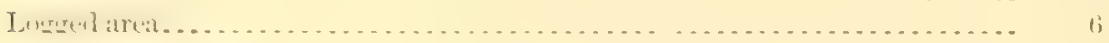

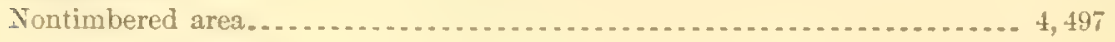

Estimate of timber in Douglas County, Washington.

M feet B. M.

Yellow pine . . . . . . . . .

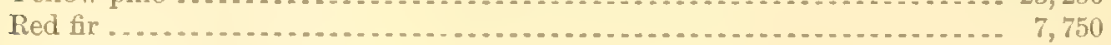

Total ... . . ............................................ 31,000

Average stand per acre, in feet B. M. ....................... 1,000 
FERRY COUNTY.

This is a new county, formed in 1899 from the western part of Stevens County, in the northeastern part of the State. Its surface is almost entirely mountainous and broken, and is throughout covered with timber, although the timber is nowhere dense. But one burn of any magnitude has occurred in the county in recent times, and no appreciable amount of timber has been cut.

Area of timber and other lands in Ferry Counly, Washingion.

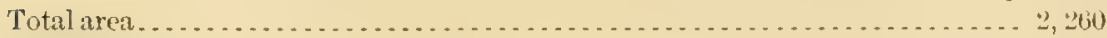

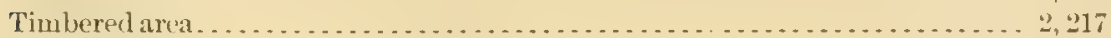

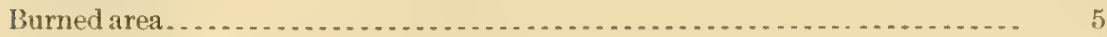

Nontimbered area............................ 38

Estimate of timber in Ferry County, Ilashington.

Pine. .....

Red fir . . . . . .

Larch ... . . . . . . . . . . .

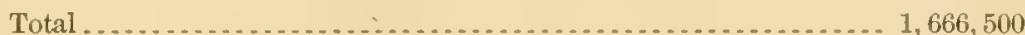

Average stand per acre, in feet B. M . . .

FRANKLIN COUNTY.

This county, which lies in the southeastern part of the State, in the angle between Snake River and the Columbia, is entirely timberless.

\section{GARFIELD COUNTY.}

This county lies in the southeastern part of the State, extending from Snake River southward to the Oregon line. The southern part includes a narrow section of the Blue Mountains. These are forested except on the northern slope, which has been largely cut over. 'The northern portion of the county is comprised in the undulating plain of Snake River and is timberless.

Area of timber and other lands in Garfield County, Washington.

Total area. . . . . .

Timbered area . . . . . . . . . . . . . . . . . . . . . . . . . . . .

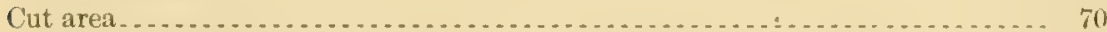

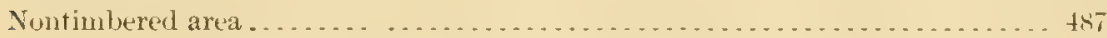

Estimate of timber in Garficld County, Washington.

M feet B. M.

Pine........................................................ 89,820

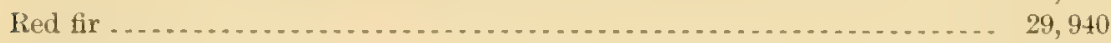

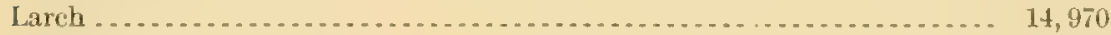

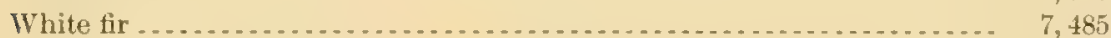

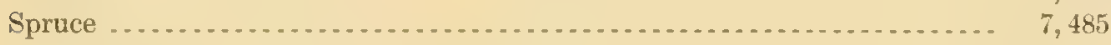

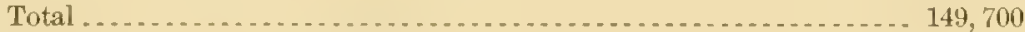

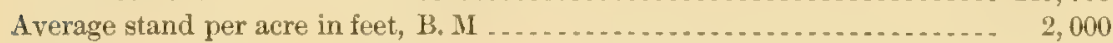


Scattered orel the cut area is standing timber to the amount of about 20 million feet, which, added to the above figures, gives a total for the county of $169,700,000$.

\section{ISIAAND COUNTY.}

This comprises a group of islands in the northern part of Puget Sound, including Whidbey and Camano islands. These islands originally were entirely covered with fir forests, but have been almost completely denuded by the ax.

Area of timbered and other lands in Island County, IIashington.

sq. miles. 220

Total area, all logged.

Estimate of timber in Island County, Washington.

M feet B. M. Fir. 250,000

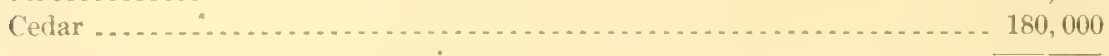

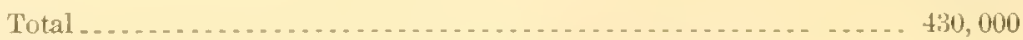

The above timber is reported as still standing upon culled land.

TEFFERSON COUNTY.

This county lies upon the Olympic Peninsula, stretching from Hood Canal, upon the east to the Pacific Ocean. 'The central portion of the county, comprising three-fourths of it, lies within the Olympic Mountains, and contains no timber of present value for milling purposes. Elsewhere the county was formerly hearily forested, on the east with fir, on the west mainly with cedar and spruce. The timber of the eastern portion has been largely destroyed either by the ax or by fire, mainly by the latter. The timber in the western portion of the county has as yet suffered little from either cause.

The forests of this county are remarkable because of the large proportion of cedar, more than half the forest being of this species, while of fir, elsewhere the most abundant species, there is comparatively little.

Area of timbered and other lands in Jefierson County, Washington.

Sq miles

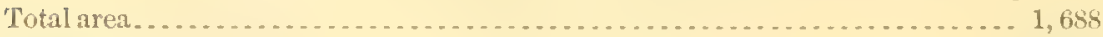

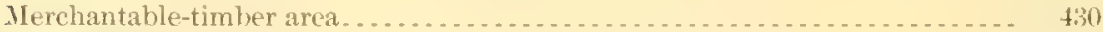

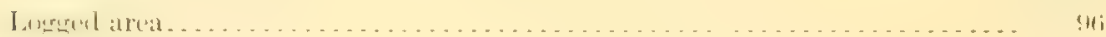

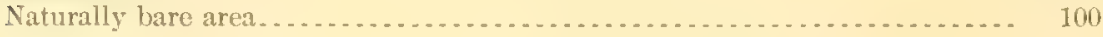

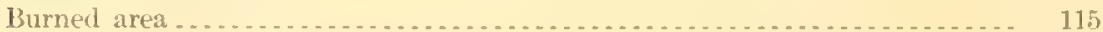

Estimate of timber in Jefferson County, Wrishington.

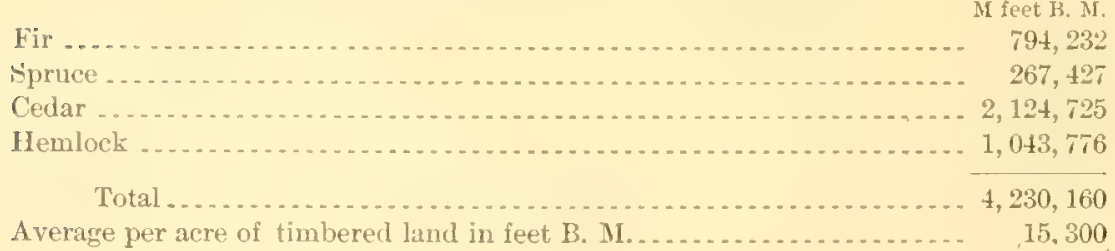


KING COUNTY.

This county is in the middle of the State north and south, and extends from the crest of the Cascade Range westward to the shores of Puget Sound. Much of the eastern part of the county lies high up in the Cascade Range, and contains little timber of present merchantable value. Aside from this and a few trifling areas of prairie, the county was originally heavily forested, but the forests have been largely removed by fire or the ax. The latter has taken the timber from Vashon and Maury islands, from the shores of Puget Sound, and of Lakes Washington and Sammamish, and from a broad belt along the line of the Northern Pacific Railway, together with other smaller areas in the interior of the county. Fires have done a vast amount of damage in various parts of the county, mainly in its central portion, although the nountainous regions have not escaped injury. Indeed, fully one-half of the area formerly covered with merchantable timber has been devastated by fire.

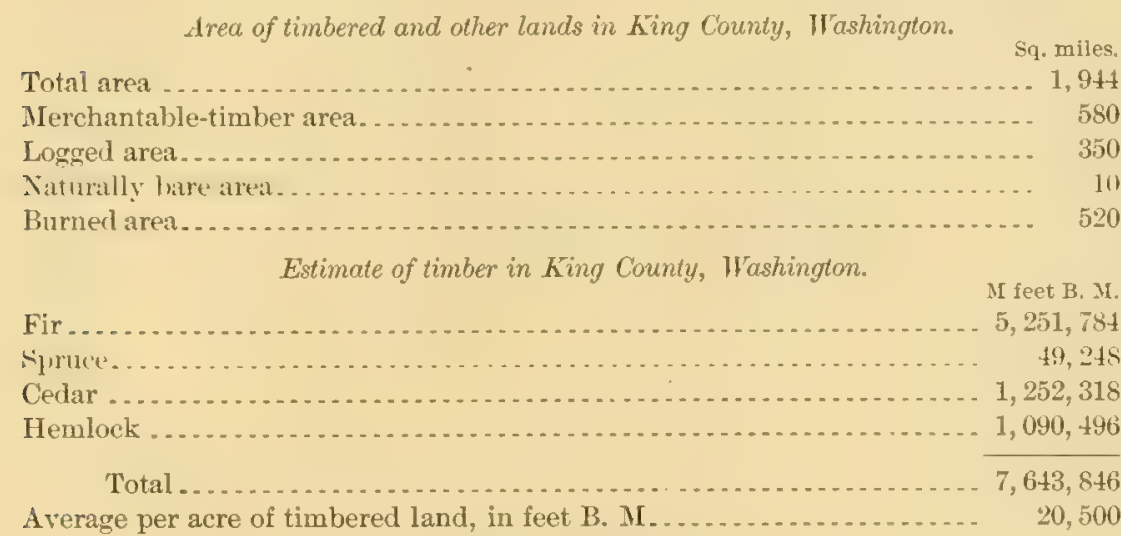

\section{KITSAI COUNTY.}

This occupies the northern part of the peninsula separating Hood Canal from Puget Sound. It was originally entirely covered with heary fir forests. These have been removed almost entirely by the ax from the shores and the islands bordering them. Only a trifling area in the southern portion of the county has been burned, while nearly half the area has been logged. The standing timber consists entirely of fir.

Area of timbered and other lands in Kitsap County, Washington.

$$
\text { Area of timbered and other lands in Kitsop County, Wiles. }
$$

Trtal area. . . . . . . . . . . . . . . . . . . . . . . . . . . . . .

Merchantable-timber area. . . . . . . . . . . . . . . . . . . . . . . . . . . . . . . 200

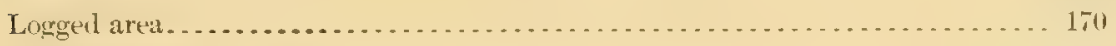

Burned area ...................................................... 22

Estimate of timber in Kitselp count!, Washingion.

M feet B. M. $1,140,900$

Fiverage per acre of timbered land, in feet B. M.......... 9,000 
This county lies in the middle of the State north and south, and streches from Columbia River to the crest of the Cascade Range. The southeastern portion of the county is within the plains region, while the western portion comprises high and rugged mountain spurs. The plains portion is without timber excepting in a narrow strip along the Iakima River. 'The mountain portion is timbered, but by no means heavily, with yellow pine, fil, and larch. Some timber has been cut from this area, especially west of Ellensburg, and in patches in the mountains in the neighborhood of the Northern Pacific Railway. The burnt areas are tritling in extent.

Aree of timber and other lands in Kittitas County, Washington.

sq. miles.

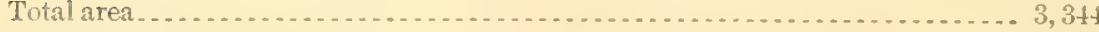

Merchantable-timber area ... . . . . . . . . . . . . . . . . . . . . . . . . . 2, 000

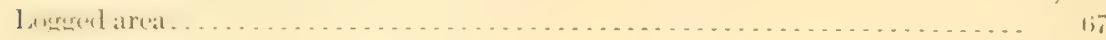

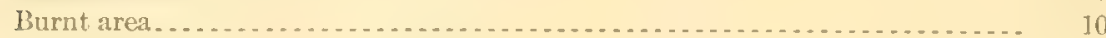

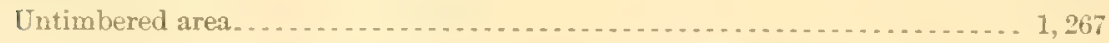

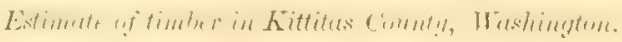

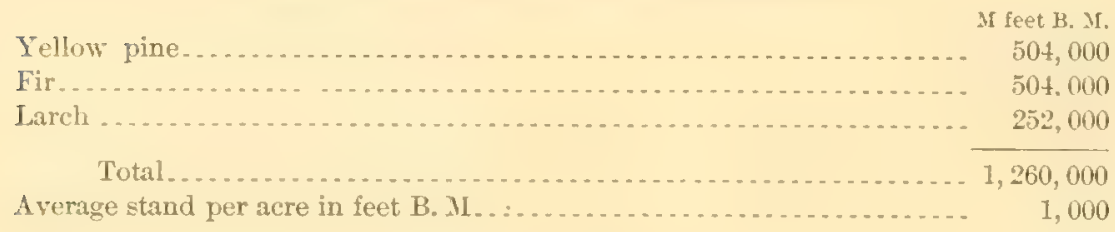

KLICKITAT COUNTY.

This county occupies a long, narrow strip bordering upon Columbia River. Its western end is in the foothills of the Cascade Range, whence it stretches far eastward into the plains. The western portion of the county is timbered, and in certain small areas quite heavily timbered. The eastern portion, comprising by far the largest part of the county, is without forests. A few small areas hare been cut, and at the western end of the county the great burns of the adjoining county, Skamania, have extended into it. These burns have occurred in recent. years, and restocking is only just commencing upon them.

Area of timber and other lands in Klickitat County, Washington.

Totol area - Sq. miles

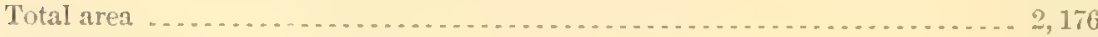

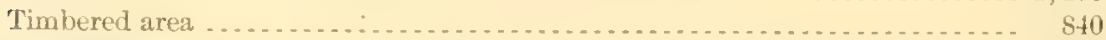

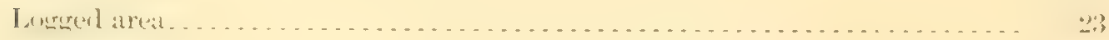

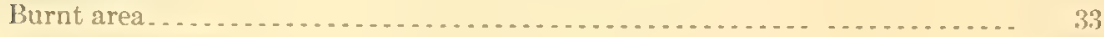

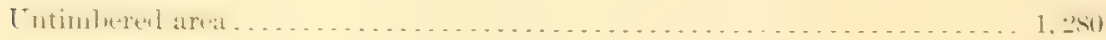


Estimate of timber in Klickilat County, Washington.

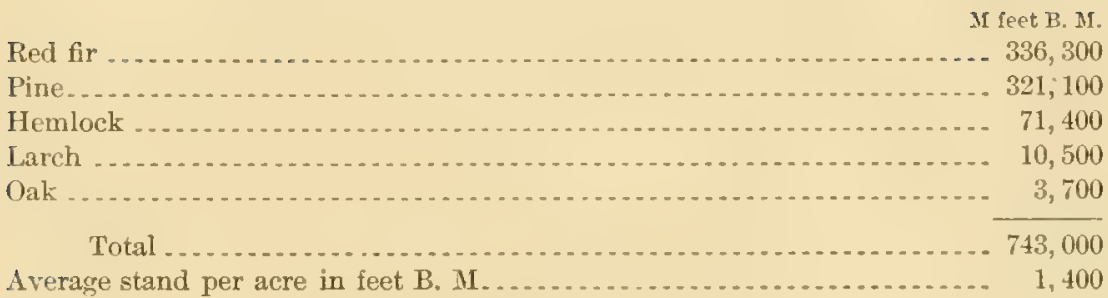

LEWIS COUNTY.

This is situated in the southwestern part of the State, and extends from the crest of the Cascade Range on the east to the Coast Ranges on the west, including the valley of Cowlitz River. A considerable portion of its area, therefore, is included within the Cascade Range, where the timber is not regarded as of present merchantable value. There are many prairies scattered over its surface, which further reduce the original area of merchantable timber.

The timber upon more than one-third of the area of this county has been burned, the burned areas lying mainly in the eastern half of the county, though they are not by any means confined to this part. The cutting of timber has been carried on mainly in the neighborhood of the Northern Pacific Railway, which traverses the county from north to south.

Area of timbered and other lands in Lewis County, Washington.

$$
\text { Sq. miles. }
$$

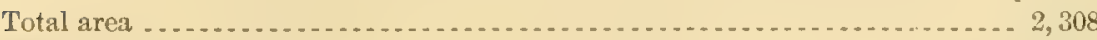

Merchantahle-timber area.................................... 815

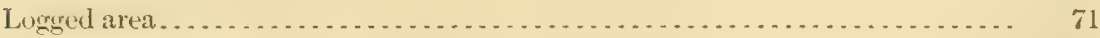

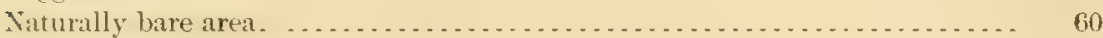

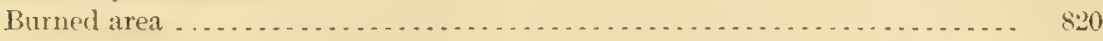

Estimate of timber in Lewis County, Washington.

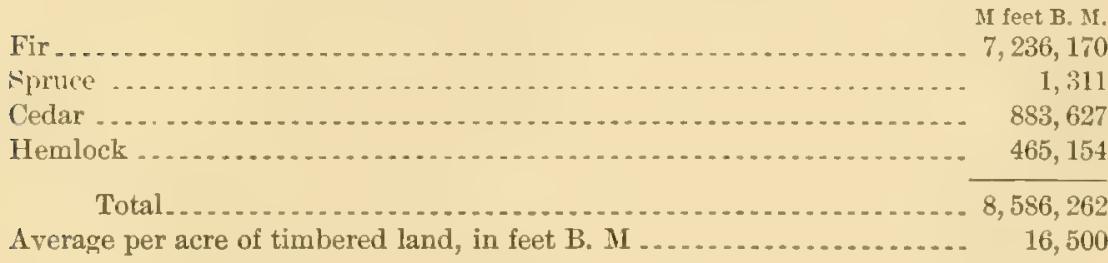

\section{LINCOLN COUNTY.}

This county lies in the eastern portion of the State, upon the Great Plain of the Columbia, and is bordered on the north by Columbia and Spokane rivers. Its surface is a broad, undulating, basalt plain, traversed by a few stream courses and numerous coulees. The timber consists mainly of yellow pine, and is found in the northern 
part of the county, near Columbia and Spokane rivers. Formerly it extended in a continuous belt across the county in the neighborhood of these streams, but most of it has been eut away for cord wood and saw logs. The stand is rery light.

Area of timbered and other lands in Lincoln County, Washington.

Sq. miles.

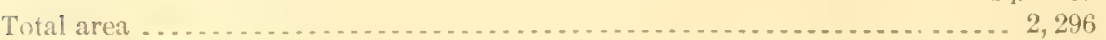

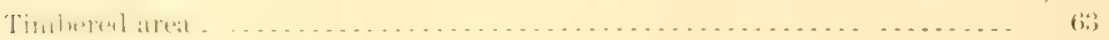

I,

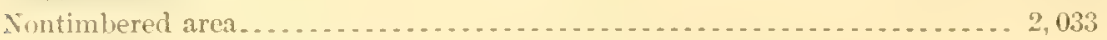

Estimate of timber in Lincoln County, Hashington.

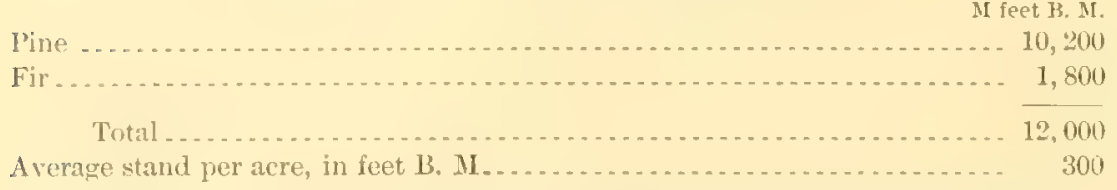

Scattered over the cut area is a little standing timber, amounting to about 2 million feet, which, added to the above estimate, gives a total of 14 million feet for the county.

\section{MASON COUNTY.}

This county includes the southeastern part of the Olympic Mountains and much of the country bordering Iood Canal. The portion within the Olympic Mountains is not regarded as containing timber of merchantable value. Elsewhere, however, with the exception of a fer small prairie tracts, it was originally heavily timbered. Fires have done little damage, but timber cutting has been extensive. 'The forests have been removed from the shores of Hood Canal and other inlets from Puget Sound, as well as from much of the interior of the county; indeed, it appears that nearly two-fifths of the area has been logged.

The forest consists almost entirely of fir, the amounts of other species being tritting.

Area of timbered and other lands in Mason County, Washington.

sq. miles.

Total area . . . .

Merchantable-timber area . . . . . . . . . . . . . . . . . . . . . . . 575

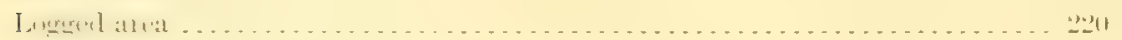

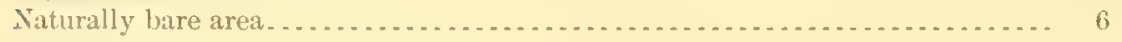

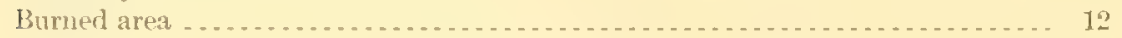

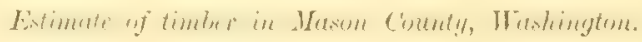

M feet $\mathrm{B}$. MI.

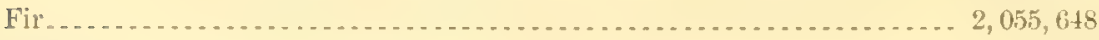

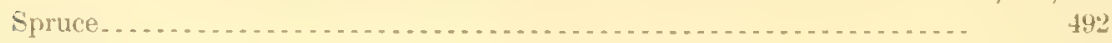

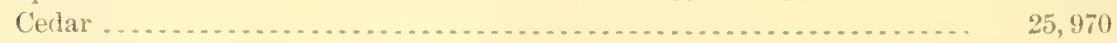

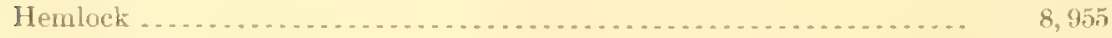

Total ......................................

Average per acre of timbered land, in feet B. MI . . . . . . . . . . . . . . 5,600 


\section{OKANOGAN COUNTY.}

This large county lies in the northern part of the State, against the Canadian boundary, and about midway between the east and west boundaries. A large part of this county is comprised within the limits of the Washington Forest Reserve, and is not considered as containing any merchantable timber under present standards. Most of the remaining part of the county is timbered but little. It is, in the main, a mountainous region, containing, however, the broad valley of Okanogan River, which traverses it from north to soutb, while along the southern edge flows Columbia River in a narrow valley. No lumbering has been earried on in the county, and the forests have not suffered in recent times by fire.

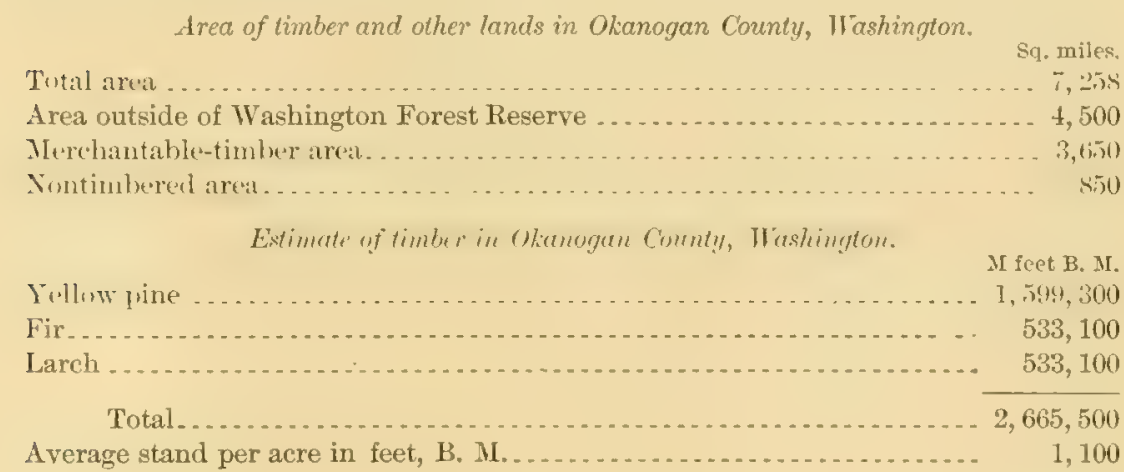

\section{PACIFIC COUNTY.}

This is the southwesternmost county of the State, bordering upon the Pacific Ocenn and Columbia River. In the interior its surfrce is somewhat broken by the Coast Ranges, although the relief is nowhere great. It is drained by Willapa and Nasel rivers.

Originally the entire surface, with the exception of a few sandy tracts near the coast, was covered with fine forests, composed almost entirely of fir in the interior, and of cedar and spruce near the coast.

Logging has been carried on along the two rivers above mentioned, and to some extent immediately on the coast. Altogether only an area of 42 square miles has been logged.

Fires have not been especially prevalent or destructive in this county, having destroyed the timber upon an area of only 59 square miles.

Area of timbered and other lands in Pacific Counly, Washington.

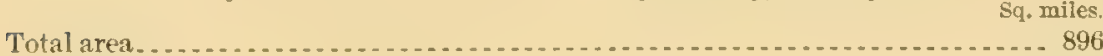

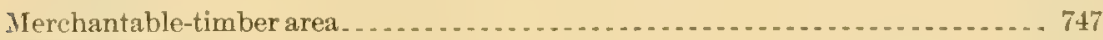

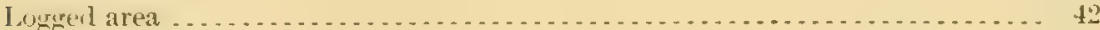

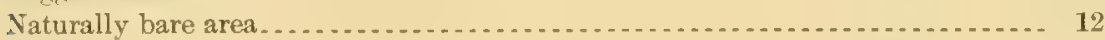

Burned area . . . . . . . . . . . . . . . . . . . . . . . . . . . . . . . . . 59 


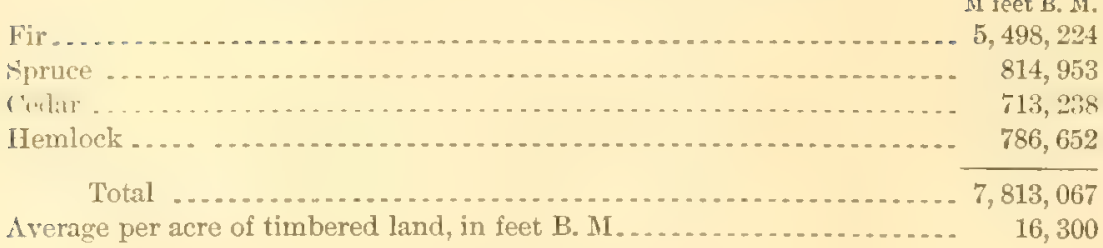

PIERCE COUNTY.

This, one of the western counties of the State, extends from the crest of the Cascade Range westward to Puget Sound, and includes several islands in the Sound. In the east itincludes Mount Rainier, with an altitude exceeding 14,500 feet, from whose summit radiate great areas of snow and ice. A large area in the eastern part of this county contains no timber of merchantable value at present. A considerable area has been logged, including nearly all of the islands, large tracts around the city of Tacoma, and others along White and Puyallup rivers.

This county has been singularly free from fires, only a trifling area having as yet been burned. There are, however, large tracts, covering many scores of square miles south of the city of Tacoma, which are naturally timberless.

Area of timbered and other lands in Pierce County, Washington.

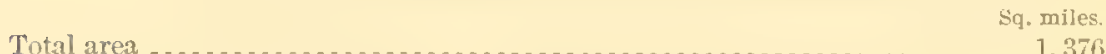

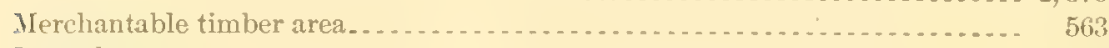

Logged area................................................. 200

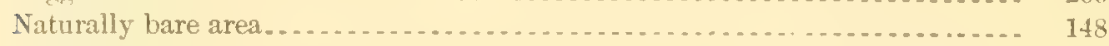

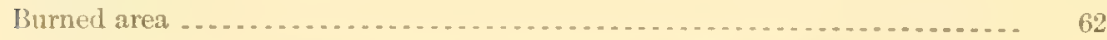

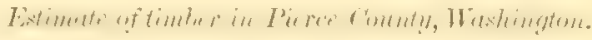

M feet B. M.

Fir ...................................................... 4, 778,091

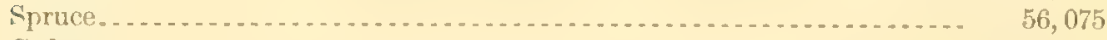

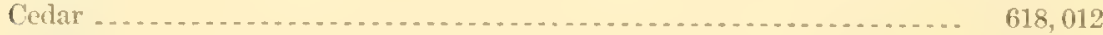

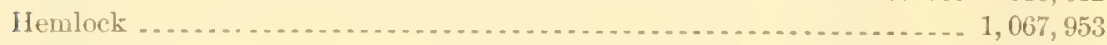

Total ................................................ $\overline{6,520,131}$

Average per acre of timbered land, in feet B. M................ 18,000

SAN JUAN COUNTY.

'This, one of the northwestern counties of the. State, is composed entirely of islands in Puget Sound, the principal of which are San Juan, Orcas, Lopez, Blakely, Shaw, and Waldron.

All these islands were originally covered with a heavy forest, composed of red fir almost exclusively, but, being easily accessible, the entire area has been logged. 


\section{SKAGIT COUNTY.}

This is in the northwestern portion of the State, and extends from the crest of the Caseade Range to Puget Sound, including a number of islands in the sound. The eastern portion, including much more than half the county, being mountainous, is not regarded as'containing merchantable timber. The western portion, comprising perhaps one-third of the county, was formerly entirely forested, with the exception of a considerable tract of prairie about the mouth of Skagit River.

There have been no fires of magnitude within the county, but logging has been extensively carried on. The islands have been cleared entirely, and the lands in the neighborhood of the coast and the immediate valley of Skagit River have been cleared as far up as the mouth of the Sauk.

Area of timbered and other lands in Skagit County, Washinglon.

Sq, miles.

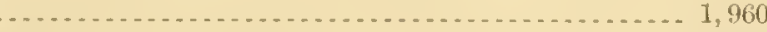

Merch:untable-timber ara. . . . . . . . . . . . . . . . . . . . . . 575

Lugred area . . . . . . . . . . . . . . . . . . . . . . . . . . . . . . . 196

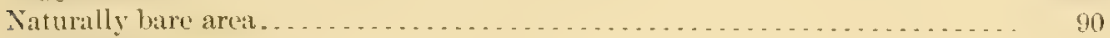

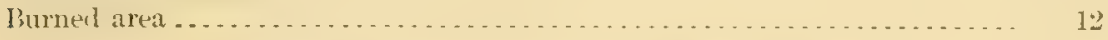

Estimate of timber in skatgit Connty, Whathingtom.

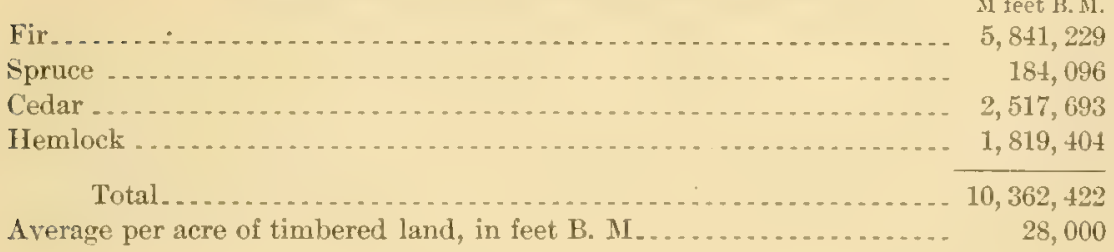

SKAMANIA COUNTY.

This county is in the southern portion of the State, bordering on Columbia River, and extending thence north ward well into the Cascade Range. In the northwestern portion of the county is the extinct volcano of St. Helens, while well into the northeast extend the western spurs of Mount Adams. The northern portion of the county is therefore extremely rugged, mountainous, and elevated, and the spurs from these mountains extend southward nearly to Columbia River.

The northern half of the county is not regarded by lumbermen as containing any accessible merchantable timber, although with the exception of the summits of the highest mountains, which are above timber line, it was formerly wooded. The southern half was at one time timbered quite heavily, especially toward the west. In recent years, however, fires have destroyed the timber in more than half the area of the county. These fires have invaded the eastern and western portions, leaving 
between them anarrow belt of forests, together with a broad stripalong Columbia River; indeed, the timber upon more than half the area of the county has been thus destroyed.

But little of the timber of this county has been cut. Logging operations extend along Columbia River across the county, reaching perhaps a mile back from the river and up a few of the streams flowing into it.

The forests of this county consist almost entirely of fir and hemlock. The amount of cedar is tritling and there is no spruce in the county.

Area of timbercd and other lands in Skamania County, Washington.

So. miles.

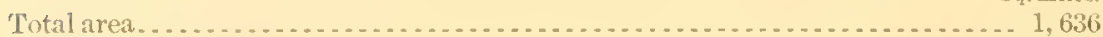

Merchantable-timber area . . . . . . . . . . .

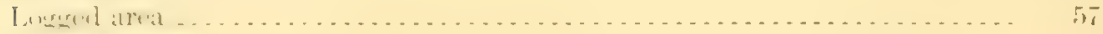

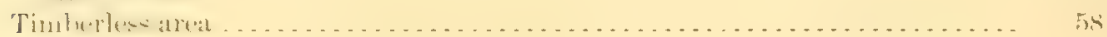

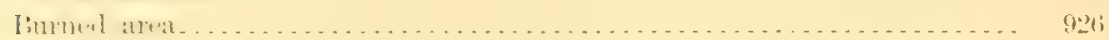

Estimate of timber in Skamania County, Washington.

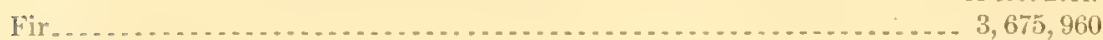

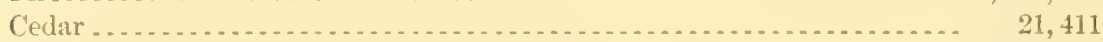

Hemlock ... . . . . . . . . . . . . . . . . . . . . . . . . . . . . . 963,759

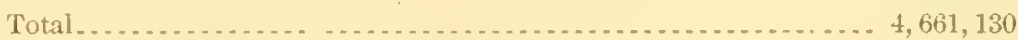

Average per acre of timbered land, in feet B. M.................... 17,000

\section{SNOHOMSH COUNTY.}

This county extends from the crest of the Cascade Range to Puget Sound. The eastern part is composed of high and rugged mountains, and contains little, if any, merchantable timber. 'The western half was originally forested, with the exception of a few tracts of prairie. Logging has, however, been carried on extensively in this county, twofifths of the area formerly timbered having been stripped by the ax. Burns have not been extensive or destructive.

The forest consists of fir and cedar, the amount of hemlock being tritting, with no spruce whatever.

\section{Area of timbered and other lands in Snohomish County, Washington.}

the miles.

II erchantable-timber area.................................. 634

Logged area.................................................... 280

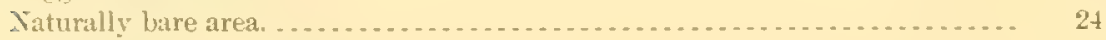

Burnedarea. . . . . . . . . . . . .

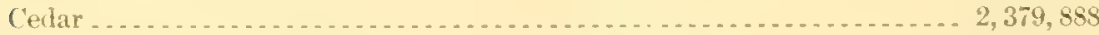

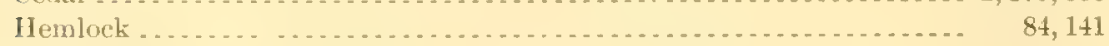

Total ....................................... $\overline{7,708,770}$

Average per acre, in feet B. M. ............................. 19, . . . . . . . . 
SPOKANE COUNTY.

This county borders upon the Idaho boundary and lies about midway between the north and south boundaries of the State. The eastern part is somewhat hilly and broken, while the western part consists of a portion of the great basaltic plain of the Columbia, intersected by numerous coulees, but traversed by few flowing streams.

Much of the area of this county was formerly timbered, but the timber has been, in great part, cut away to supply the needs of the city of Spokane and other towns. Very little of the timber has suffered from fire.

Area of timber and other lands in Spokane County, Irashingion.

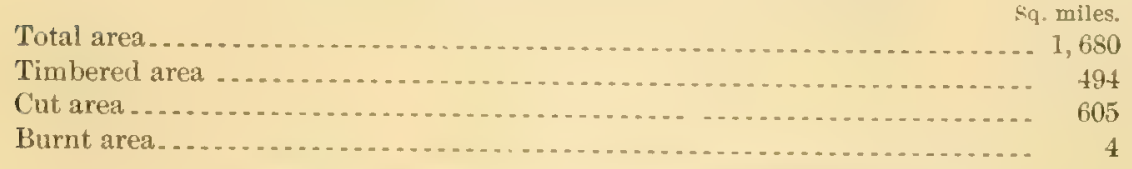

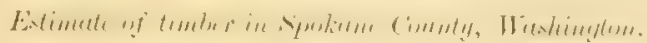

II feet B. M.

Pine...

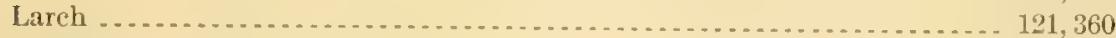

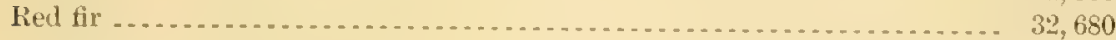

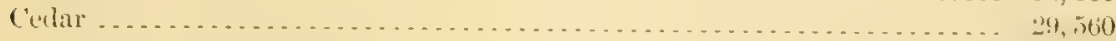

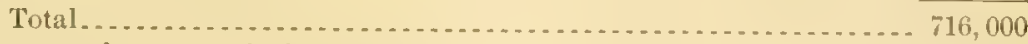

Average stand peracre, in feet 13. MI . . . . . . . . . . . . . . . . . . . . 300

Scattered over the cut area there is still standing scattered timber estimated altogether at 50 million feet, which, added to the above, gives a total of $\pi 66$ million feet for the county.

\section{STEVENS COUNTY.}

This is the northeastern county of the State. It is bordered on the west by Columbia River, while much of its southern boundary is formed by Spokane River. It is, in the main, a mountainous region, but is intersected by the broad valleys of Clark Fork and other streams. Nearly all of its area is timbered, but nowhere densely. Burned areas are more extensive here than in any other of the eastern counties, and there has been considerable cutting in scattered localities.

The species of timber found in the county consist of pine, in which is included both yellow and western white pine, which are not distinguished, red fir, larch, and cedar. In the western portion of the county, along Columbia River, the timber consists almost entirely of pine, only $t$ per cent being fir and 1 per cent larch. In the neighborhood of Colville River the proportion of pine diminishes to 75 per cent, and that of fir and larch increases to 10 per cent each, while the proportion of cedar reaches 5 per cent. In the southeastern part of the county the proportion of pine is still further reduced to 60 per 20 GEOL, PT $5-3$ 
cent, while larch increases to 30 per cent, the remainder being made up of equal proportions of fir and cedar. Along the line of the Great Northern Railway, in the southern conner of the county, the proportion of larch is still greater, reaching 50 per cent in certain small areas.

Aren of timber and other lands in stevens County, Washington.

sin. miles.

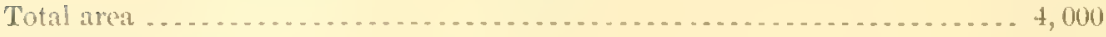

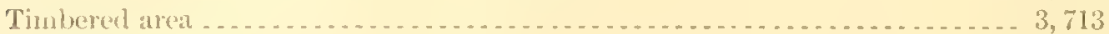

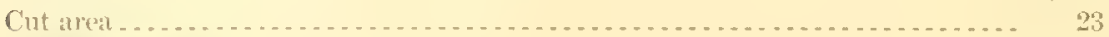

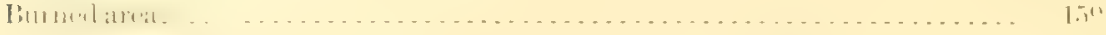

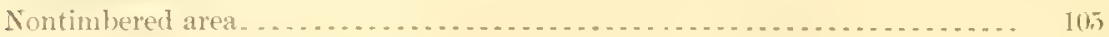

Estimate of timber in Sterens County, II ashington.

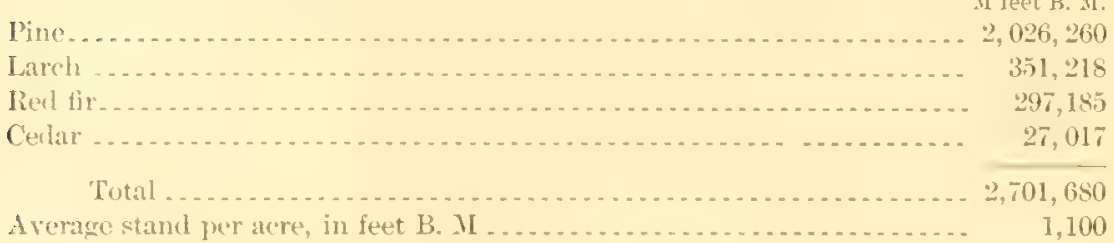

THURTON COUNTY.

This county lies in the western part of the State, hordering on the north upon Puget Sound. Its area was, with the exception of numerous prairie tracts, originally covered entirely with tine forests, mainly of fir. It present all the forests in the neighborhood of Puget Sound have been eut aray. Fires have not been prevalent and but little timber has been destroyed by this means.

. Iree of limbered and other lamels in Therston County, Washington.

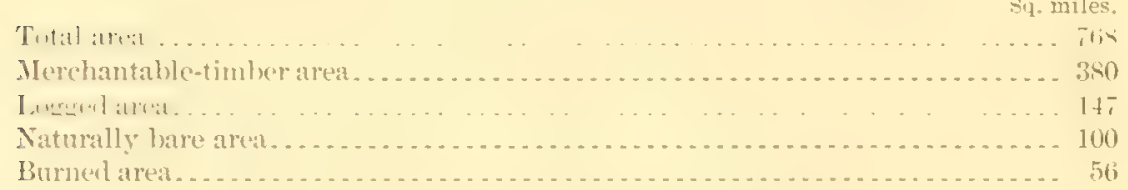

Estimate of timber in Thurston Conchly, Washington.

II feet $\mathrm{B}$. M.

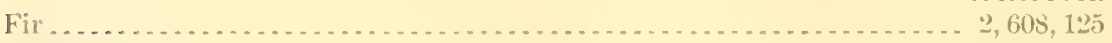

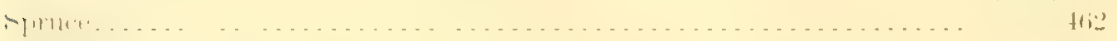

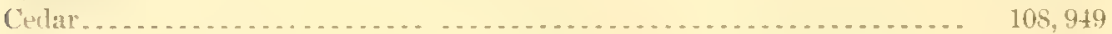

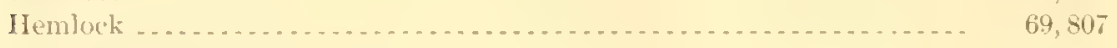

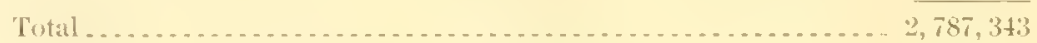

Arerage per acre of timbered land, in feet 13. M . . . . . . . . . . . . . . 11,050

WAHKIAKM COUNTY.

This county lies in the southwestern part of the State, bordering on Columbia River. With the exception of certain islands in the Columbia and small tracts about the mouths of certain tributary streams. 
the entire area was heavily forested. Lumbering has been carried on along the shores of the Cohmbia and on Gray and Deep rivers. Fires also have been somewhat prevalent in the county, but more than twothirds of the area of the county is still covered by fine forests.

Area of timbered and other lands in Wahkiakum Conmty, Washington.

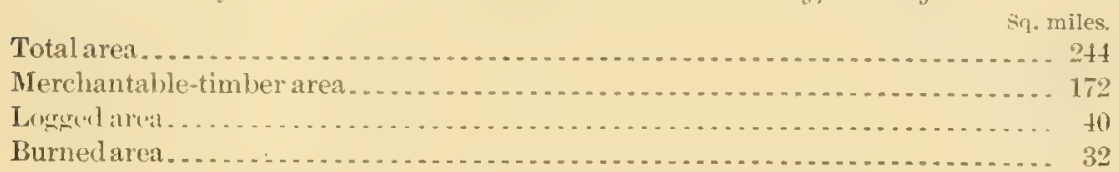

Estimate of timber in Wahkiakum County, Washingion.

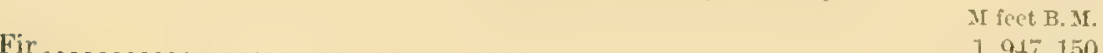

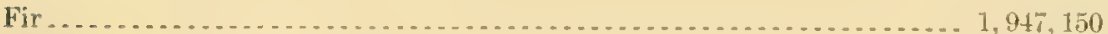

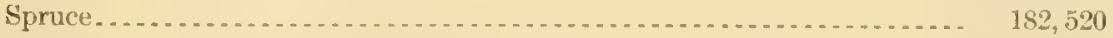

Cerlatr . . . . . . . . . . . . . .

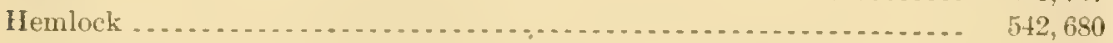

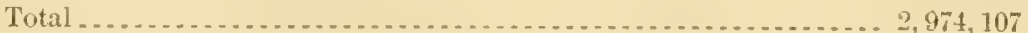

Average per acre of timbered land, in feet B. M. . . . . . . . . . ....... 27,000

WAIAAWALIA COUNTY.

This county lies in the southern part of the State, being bordered on the north by Snake River and on the west by Columbia River. Its surface is an undulating plain, sloping northward and westvard from the Blue Mountains.

The amount of timber in this county was originally small, and this has been entirely logged off, with the exception of about $4,500,000$ feet left standing after logging operations. Of this about half is pine, onefourth fir, and one-fourth larch.

\section{WHATCOM COUNTY.}

This is the most northern county of the State west of the Cascade Range. It extends west from the summit of the range to the shores of Puget Sound. In the eastern half of the county are found Mounts Baker and Shuksan, two great extinct volcanoes, rising high above timber line. This eastern mountainous half of the county is not regarded as containing any timber of present merchantable value. The western half was originally very hearily timbered. Its forests were probably as deuse as in any other county in the State, but they hare been almost entirely destroyed by fire. Certain areas along the coast, on Nooksak River and on the Bellingham Bay and British Columbia Railroad, have been logged, but the amount of timber thus utilized is small as compared with that destroyed by fire. To illustrate the extent of this derastation it may be stated that out of a timbered area of 780 square miles not less than 530 square miles have been burned; $16 t$ square miles have been logged, and only 86 square miles of timber of present merchantable value are to be found in the county. 
The forest consists almost entirely of fir and cedar, the amounts of hemlock and spruce being trifling.

- Irea of timbered and other lands in Whatcom County, Washington.

Sil. miles.

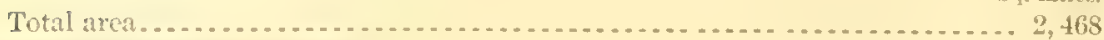

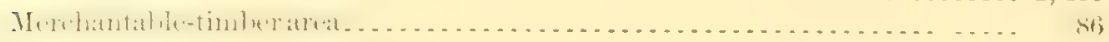

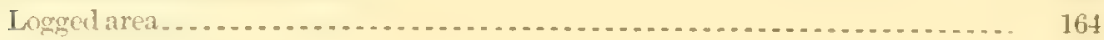

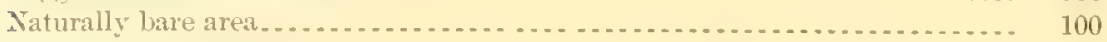

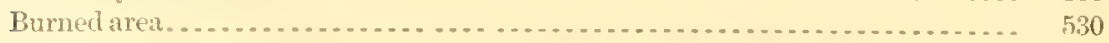

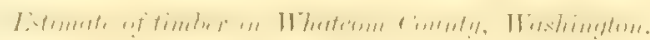

Fir . . . .

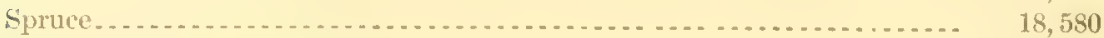

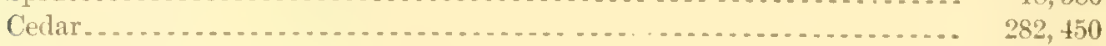

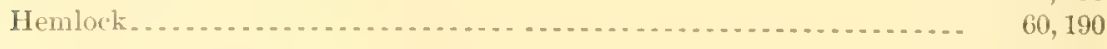

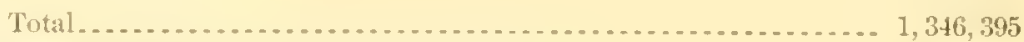

Average per acre of timbered land, in feet B. II ................ 24,000

\section{WHITMAN COUNTY.}

This county is in the eastern part of the State, bordering upon Idaho. Its surface is a broadly undulating plain, with a surface of basalt sloping to the eastward.

It formerly contained a few small areas of timber land in the enstern and northern parts, but these have been logged over, leaving, however, a small amount of timber still standing.

Area of timber und opher lands in Whitman County, Wreshington.

sil. miles.

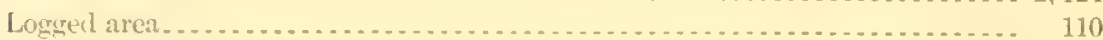

Nontimbered area ......................................... 2, 2,014

In the cut areas there is still standing a little timber, estimated at 35 million feet, consisting mainly of yellow pine.

\section{TAKIMA COUNTY.}

This county lies in the middle southern portion of the State, being bordered upon the east by Columbia River, and extending on the west to the crest of the Cascade Range. The restern portion of the county is included within the Mount Rainier Forest Reserve. The estimates of area and of stand of timber do not include the reserve portion.

The eastern portion of the county consists of a broadly undulating plain, and is without forests. The western portion lies in the Cascade Range, is mountainous and broken, and is timbered throughout, but for the most part not heavily. There has been considerable cutting in the lower edges of the mountain forests, particularly upon the Naches River, where a large area has been logged. There are no burns except in the southwest corner of the county. 
Area of timber and ather lands in Yakima County, Washington.

Total area ....... Sq. miles.

Area outside of Mlount

Area outside of Mount Rainier Forest Reserve.................... 4,587

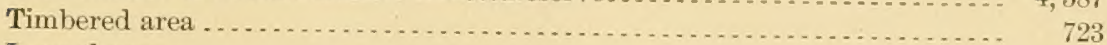

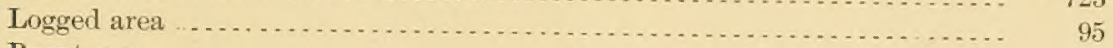

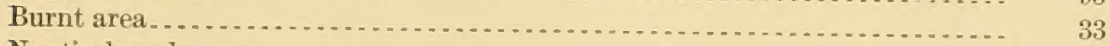

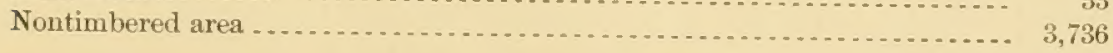

Estimate of timber in Yakima County, Washington.

Fir.

Pin

H

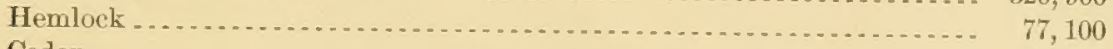

Cedar ................................................ 60,600

Total ........................... 893,498

Average stand per acre in feet B. M ............................ 1,900 


